\title{
$\beta$-Caryophyllene from Chilli Pepper Inhibits the Proliferation of Non-Small Cell Lung Cancer Cells by Affecting miR-659-3p-Targeted Sphingosine Kinase I (SphKI)
}

Jiaji Lei

Qiushi Wang (ID

Guanghua Li

Yongchao Li

Pengfei Zhang

Guangquan Xu (D)

Department of Second Ward of Thoracic Surgery, The Second Affiliated Hospital of Harbin Medical University, Harbin,

I570I I, People's Republic of China
Correspondence: Guangquan Xu Department of Second Ward of Thoracic Surgery, The Second Affiliated Hospital of Harbin Medical University, No. 246 Baojian Road, Nangang District, Harbin, I570 II, People's Republic of China Tel/Fax +86-045I-8629724I

Email xuguangI2quan@I63.com
Background: $\beta$-Caryophyllene is the main ingredient of chilli pepper and used for the prevention of various cancers, while the molecular mechanism for its effects on non-small cell lung cancer (NSCLC) remains unclear.

Methods: NSCLC cell lines A549 and NCI-H1299 were treated with $\beta$-Caryophyllene and miR-659-3p (a potential tumor suppressor) mimic or siRNA. The levels of miR-659-3p, sphingosine kinase 1 (SphK1), apoptotic factors and oxidative stress factors were investigated.

Results: $\beta$-Caryophyllene inhibited NSCLC growth, promoted their apoptotic rate, increased the level of miR-659-3p, apoptotic factors (cleaved caspase-3 and BAX), antioxidant factors (SOD, CAT and GPx) and reduced the level of oxidative stress (ROS and NO) and SphK1. miR659-3p mimic and siRNA affected NSCLC growth, their apoptosis, and biochemical indices.

Conclusion: $\beta$-Caryophyllene of chilli pepper exerts inhibitory activity in NSCLC cells possibly by affecting miR-659-3p-targeted SphK1.

Keywords: $\beta$-caryophyllene, chilli pepper, non-small cell lung cancer, miR-659-3p, sphingosine kinase 1

\section{Introduction}

Lung cancer is the malignant tumor with the highest morbidity and mortality among all tumors. ${ }^{1}$ The widespread and global incidence of lung cancer requires more advanced treatment methods. In the global survey and analysis of lung cancer, the incidence of non-small cell lung cancer (NSCLC) is as high as $85 \%$, which is significantly higher than that of small cell lung cancer. ${ }^{2}$ NSCLC is highly malignant, easy to relapse and metastasize. The first-line and traditional treatments for NSCLC include chemotherapy, ${ }^{3,4}$ radiotherapy, ${ }^{5,6}$ and surgery. ${ }^{7,8}$ In the past ten years, targeted therapy and tumor immunotherapy have become new treatment methods for NSCLC, and they have developed rapidly. The availability of new drugs has also produced more differences and side effects. ${ }^{9}$ It is necessary to explore new nature potential drug with few side effects.

Chrysanthemum boreale (Asteraceae) is a wild flowering plant in East Asia and its main ingredient $\beta$-caryophyllene exerts anti-proliferative activities in lung cancer cells A549 and NCI-H358 cells by inducing G 1 phase cell cycle arrest in human lung cancer cells. $^{10}$ However, the related molecular mechanism remains widely unknown. 
Comparatively, chilli pepper is a common vegetable with rich $\beta$-caryophyllene and can be easily available. ${ }^{11}$ Chili pepper (Capsicum annuum L.) belongs to Solanaceae Capsicum, is often used as a spice, flavour enhancer, vegetable and ingredients in traditional Chinese medicine and its many phytochemicals (alkaloids, anvils, flavonoids, phenols, unsaturated fatty acids) exert health-promoting properties, including anticancer, ${ }^{12}$ anti-inflammatory ${ }^{13}$ antioxidant,${ }^{14}$ and the metabolism of glucose and cholesterol. ${ }^{15} \beta$-Caryophyllene is often reported nature product with anti-cancer properties and widely existed in the volatile compounds of pepper and chilli pepper. $^{16,17}$ However, the impact of $\beta$-Caryophyllene on NSCLS and related molecular mechanisms remain unclear.

MicroRNA (miRNA) is a small non-coding RNA of 18-25 nucleotides, which inhibits target gene expression by directly binding to the 3'-untranslated region (3'-UTR) of mRNA. It is estimated that more than $60 \%$ of human protein-coding genes are regulated by miRNAs. ${ }^{18}$ miRNAs play a role in many physiological and pathophysiological processes, such as embryonic development, stem cell differentiation, inflammation and tumors. Much more evidence shows the key regulatory role of miRNA in various types of malignant tumors, including NSCLC. ${ }^{19,20}$ For example, miR-205 connects TMPRSS4 (a membraneanchored protease involved in cell migration and invasion in NSCLC) to accelerate the cell cycle progression of NSCLC cells. ${ }^{21}$ In addition, previous studies have shown that the expression of miR-126 decreases in A549 cells, and the up-regulation of miR-126 inhibits the proliferation, migration and invasion of A549 cells by targeting phosphatidylinositol-3-kinase regulatory subunit 2 (PIK3R2). ${ }^{22}$ miRNA also plays an important role in the chemical and radio-sensitivity of NSCLC cells by regulating DNA repair genes. ${ }^{23}$ Therefore, miRNA is a potential biomarker for the diagnosis, prognosis, prevention and treatment of NSCLC. With the progress of research, many natural Chinese medicine ingredients have been found to have the effect of regulating microRNA.

Sphingosine kinase 1(SphK1) is a key kinase for intracellular sphingomyelin metabolism. It can catalyze the production of sphingosine (Sph) to sphingosine-1-phosphate (S1P) and participate in the regulation of multiple intracellular sphingosine kinases. The transmission of important signal transduction pathways plays an important role in maintaining cell homeostasis, regulating cell proliferation, differentiation and apoptosis. Recent studies have shown that SphK1 is a carcinogenic enzyme, which is closely related to the proliferation and transformation of cells and the survival, invasion and migration of tumor cells. SphK1 gene itself has many characteristics of oncogene. The expression level of SphK1 is significantly increased in a variety of tumor tissues and tumor cells cultured in vitro, including breast cancer, colorectal cancer, gastric cancer, liver cancer, bladder cancer, endometrial cancer, etc.

miR-659-3p, a tumor suppressor, exerts its function via downregulating SphK1 by binding to its 3'-UTR and increasing the apoptosis of cancer cells. ${ }^{24} \beta$ Caryophyllene controls various diseases by regulating miRNA. ${ }^{25} \beta$-Caryophyllene has been used for exploring the prevention of various cancers, while its effects on NSCLC and the related molecular mechanism remain unclear. In this study, we investigated the inhibitory potential of $\beta$-caryophyllene on NSCLC cells and explored the underlying molecular mechanisms associated with the antioxidant properties and antitumor activities.

\section{Materials and Methods \\ Materials}

The following agents were purchased from Sigma, including 2-Methyl-1-tetralone, Catalogue Number: 1590-08-5; $\beta$ Caryophyllene, Catalogue Number: 87-44-5; $\beta$-Elemene, Catalogue Number: 515-13-9; Hexanal, Catalogue Number: 66-25-1; Furfural, Catalogue Number: 98-01-1; Nonanal, Catalogue Number: 124-19-6 and 2-methyldecane, Catalogue Number: 6975-98-0 were purchased from Zhengzhou JACS Chem Co., Ltd (Zhengzhou, China).

\section{Integrated Bioinformatics Analysis of SphKI in Lung Cancer and Interaction with Potential miRNA}

SphK1 expression in lung cancer was analyzed by using the data from GEPIA2 database, including the median expression of SphK1 in tumor and normal samples via bodymap. GEPIA2 database was used to obtain the SphK1 expression levels in lung cancer and normal tissues, such as LUAD, lung adenocarcinoma and LUSC, lung squamous cell carcinoma. SphK1 expression was investigated at different stages of lung cancer. KaplanMeier analysis was used to analyze the overall survival of lung cancer patients based on SphK1 expression in GEPIA2 database. miRDB is an online database for miRNA target prediction and functional annotations. ${ }^{26,27}$ SphK1 is predicted to be targeted by potential miRNAs via 
miRDB online tools. Finally, the target site was also analyzed.

\section{GC/MS Analysis of Volatile Compounds from Chilli Pepper}

About $1.5 \mathrm{~kg}$ of dried chili pepper was rinsed with clean water, dried, and cut into small pieces less than $1 \mathrm{~cm}$ in length. Five hundred grams was taken into a bag, and marked as $\mathrm{A}, \mathrm{B}$, and $\mathrm{C}$, and homogenized with liquid nitrogen, and stored in a freezer at $-20^{\circ} \mathrm{C}$ for later use. About $5 \mathrm{~g}$ of homogenized sample was added to $5 \mathrm{~mL}$ saturated $\mathrm{NaCl}$ solution, vortexed for $3 \mathrm{~min}$, placed in a $15 \mathrm{~mL}$ headspace bottle, and heated on a magnetic stirrer at $65^{\circ} \mathrm{C}$ for $15 \mathrm{~min}$. About $65 \mu \mathrm{m}$ PDMS/DVB was inserted into the headspace bottle, and headspace solidphase micro extraction (HS-SPME) was performed at $250^{\circ} \mathrm{C}$ for $45 \mathrm{~min}$. The powder was located about $1 \mathrm{~cm}$ above the liquid surface in the headspace bottle. The stirring speed was adjusted to $1000 \mathrm{r} / \mathrm{min}$ and heated to $80^{\circ} \mathrm{C}$. After $30 \mathrm{~min}$, the extraction tool was inserted into the inlet of the gas chromatograph at $250^{\circ} \mathrm{C}$ for $5 \mathrm{~min}$. GCMS instrument was operated, and data acquisition and analysis were performed.

The instrument includes Agilent HP-5MS chromatographic column $(30 \mathrm{~m} \times 250 \mu \mathrm{m} \times 0.25 \mu \mathrm{m})$. The carrier gas was helium, the linear flow rate was set at $1 \mathrm{~mL} / \mathrm{min}$, the inlet temperature was $250^{\circ} \mathrm{C}$, the desorption temperature was $250^{\circ} \mathrm{C}$, and the desorption time was $5 \mathrm{~min}$. The sample was injected in split mode, and the injection volume was 1 $\mu \mathrm{L}$. The heating program was set to an initial temperature of $40^{\circ} \mathrm{C}$, maintained for $5 \mathrm{~min}$, heated to $160^{\circ} \mathrm{C}$ at $4^{\circ} \mathrm{C} / \mathrm{min}$, maintained for $5 \mathrm{~min}$, and then heated to $250^{\circ} \mathrm{C}$ at $6^{\circ} \mathrm{C} / \mathrm{min}$, maintained for $5 \mathrm{~min}$. Mass spectrometry condition was proved as follows: ion source type $\mathrm{EI}, 70 \mathrm{eV}$; ion source temperature and interface temperature were both $230{ }^{\circ} \mathrm{C}$; quadrupole temperature $150{ }^{\circ} \mathrm{C}$. It adopted full scan mode, and the mass scan range was $35 \sim 450 \mathrm{~m} / \mathrm{z}$.

After the data were collected using the Agilent 7890B/ 597A gas chromatography-mass spectrometer system, the data were analyzed by using the Mass Hunter GC/MS Acquisition Software (B.07.00) and MSDChemStat 1.0. According to the automatic search and matching of the structural formula of each peak in the data spectrum, with the aid of manual analysis, the mass spectrum of each compound was compared with the standard spectrum, and the retention index was combined with the literature for qualitative analysis; the peak area normalization method was used for quantification analysis. Finally, volatile compounds were identified by matching retention times and mass spectra with authentic standards.

\section{Cell Culture}

NSCLC cell lines A549 and NCI-H1299 were purchased from Shanghai Institute for Biological Sciences (Shanghai, China), and the cell line HCC827 and PC9 from Chengdu Yuanquan and cultured in DMEM media with 10\% heatinactivated fetal bovine serum (FBS), penicillin $(100 \mathrm{u} /$ $\mathrm{mL})$, and streptomycin sulfate $(100 \mu \mathrm{g} / \mathrm{mL})$. Cells were cultured at $37{ }^{\circ} \mathrm{C}$ and $5 \% \mathrm{CO}_{2}$.

\section{Cell Transfection}

The following sequences were synthesized from TaKaRa Biotechnology Company, miR-659-3p siRNA, 5'-GAAC CAAGGAAGAGTCACAGT-3'; siRNA scrambled, 5'GGCAAACCAGGGAAATACGTA-3'; miR-659 mimic, 5'-CTTGGTTCAGGGAGGGTCCCCA-3 and miR-6593p mimic scrambled, 5'-GGTGCTAGGCGCTCGC TCATGA-3'. Lipofectamine 2000 transfection reagent was used to transfect miR-659-3p, siRNA and scrambled samples according to the manufacturer's instructions. Sixwell plates were used for cell culture, and $5 \times 10^{4}$ cells were inoculated in each well of the six-well plate. Liposome-nucleic acid complex was prepared, and 250 $\mu l$ Opti-MEM was added to dilute Lipofectamine 2000, mixed well at room temperature and incubated for $5 \mathrm{~min}$. About $7.5 \mu \mathrm{l}$ miRNA mimics/siRNA was mixed with $250 \mu \mathrm{l}$ Opti-MEM and incubated at room temperature for $20 \mathrm{~min}$. The mixture was transferred to the six-well cell plate, placed in a cell incubator, and cultured at $37^{\circ} \mathrm{C}$ and $5 \% \mathrm{CO}_{2}$.

\section{MTT Assay}

Cell growth rate was measured by using MTT assay. Cells were harvested and seeded in 96-a well plate at $1 \times 10^{5} / \mathrm{mL}$ in $200 \mu \mathrm{L} /$ well. The cells were treated with 10,20 and $40 \mu \mathrm{M}$ of the individual volatiles compound standard. After 24-, 48and 72-h incubation, $50 \mu \mathrm{L}$ of MTT was added to each well for $4 \mathrm{~h}$. The supernatants were discarded, and MTT crystals were solubilized with $100 \mu \mathrm{L}$ DMSO for individual well and absorbing values were measured at $540 \mathrm{~nm}$. Inhibitory rates were calculated, $100 \% \mathrm{x}$ (the values of control cells - the values of treated cells)/the values of control cells. All cells were assigned into the following groups, $\mathrm{CG}$, control group; $\mathrm{EG}, \beta$-Elemene $(40 \mu \mathrm{M})$ treated group; IG, miR-659-3p siRNA group; ING, miR-659-3p siRNA scrambled group; 
EIG, $\beta$-Elemene treated miR-659-3p siRNA group; $M G$, miR-659-3p mimic group; MNG, miR-659-3p mimic scrambled group and EMG, $\beta$-Elemene treated miR-659-3p mimic group. Inhibitory rates were calculated and compared among different groups using the above method.

\section{Apoptosis Analysis}

After treatment with different concentrations $\beta$ caryophyllene or miR-659-3p siRNA or mimics for different time times, the cells were collected with trypsin and rinsed with ice-cold PBS twice. The pellets were resuspended and fixed in $70 \% \mathrm{EtOH}$ at $4{ }^{\circ} \mathrm{C}$ overnight. Before being detected by flow cytometry, the cells were washed twice with PBS and resuspended in a solution containing PI $(1 \mu \mathrm{g} / \mathrm{mL})$ and RNase A (10 $\mu \mathrm{g} / \mathrm{mL})$ for $30 \mathrm{~min}$. Cells were digested with $0.25 \%$ trypsin for 3 min. PBS was added to make cell suspension, and cells were mixed evenly and observed under an inverted microscope. The cell suspension was transferred into a $10 \mathrm{~mL}$ centrifuge tube and centrifuge at $4^{\circ} \mathrm{C}, 1000 \mathrm{rpm}$ for $5 \mathrm{~min}$. The supernatant was removed, and precipitation was washed twice with PBS, and centrifuged at $1000 \mathrm{rpm}$ for $5 \mathrm{~min}$, and collected. Five hundred-microliter binding buffer was added, and the cells were resuspended. Five-microliter Annexin V-EGFP was added, and then $5 \mu \mathrm{L}$ PI was added, mixed well. The mixture was centrifuged at $1000 \mathrm{rpm}$ for $5 \mathrm{~min}$, and the supernatant was removed. One hundred and ninety microliters of Annexin V-FITC binding solution was added, and $10 \mu \mathrm{L}$ of PI staining solution was added and mixed well on the ice bath for $15 \mathrm{~min}$. Flow cytometry detection was performed at excitation wavelength of $488 \mathrm{~nm}$ and emission wavelength of $638 \mathrm{~nm}$.

\section{qRT-PCR Analysis}

RNA was isolated from cells following the instructions of RNA extraction kit (Invitrogen, USA). Reverse transcription of mRNA was synthesized by using cDNA synthesis kit (TaKaRa, Japan). The primer for caspase-3 and BAX was used from the reported reports. ${ }^{28}$ The primers for miR-659-3p, SphK1, U6 and GAPDH were used from the previous report ${ }^{29}$ and synthesized from TaKaRa.

qRT-PCR was performed on Biosystems Step One Plus $^{\text {TM }}$ Real-Time PCR System (Life Technologies TM, USA). First, perform the pre-denaturation at $95^{\circ} \mathrm{C}$ for 10 min, and then alternately cycle 40 times at $95^{\circ} \mathrm{C}$ for 15 $\mathrm{s}$ and $60^{\circ} \mathrm{C}$ for $60 \mathrm{~s}$. Three parallel samples were set in parallel for each sample. The PCR system software was used for data collection and analysis. The 2- $\Delta \Delta \mathrm{CT}$ threshold cycle method was used for quantitative data analysis. GAPDH was used as the control.

\section{ELISA Analysis}

Collected cells were disrupted by using lysis buffer (1:10, $\mathrm{w} / \mathrm{v})^{30}$ and centrifuged at $12,000 \times \mathrm{g}$ for $10 \mathrm{~min}$ and the supernatant was collected. The concentration of SphK1, cleaved caspase- 3 and BAX was analyzed by using the ELISA kits from Beyontime Co. (Beyotime, China).

\section{Measurement of ROS and NO}

The DCFH-DA (2,7-dichlorofluorescein diacetate) probe was used to determine the ROS in the cells. The single-cell suspension was incubated with $10 \mu \mathrm{M}$ DCFH-DA at $37^{\circ} \mathrm{C}$ for about $30 \mathrm{~min}$ and then centrifuged at $1000 \mathrm{~g}$ for 10 min. The fluorescently labelled cells were collected and resuspended in $9 \times$ volume of PBS. The fluorescence intensity of DCF (dichlorofluorescein) in the resuspension of single cells was measured with an automatic multifunctional microplate reader (Thermo). The maximum excitation spectrum was $495 \mathrm{~nm}$, and the maximum emission spectrum was $529 \mathrm{~nm}$. The nitrate reductase method was used to determine the production of nitric oxide (NO). According to the operating instructions provided by the manufacturer of the nitric oxide kit (Nanjing Jiancheng Institute of Biological Engineering). About $0.5 \mathrm{~mL}$ of the supernatant and $0.3 \mathrm{~mL}$ of color developer were mixed and measured using a spectrophotometer (Shimadzu, Japan) at $550 \mathrm{~nm}$ wavelength.

\section{Measurement of Antioxidants}

Glutathione peroxidase (GPx) (EC 1.11.1.9) is a seleniumcontaining antioxidant that effectively reduces $\mathrm{H}_{2} \mathrm{O}_{2}$ and lipid peroxides to water and lipid alcohols. The Sod, Cat and GPx enzyme activities were measured using Sod assay kit (WST-1 method), Cat assay kit (visible light method) and GPx assay kit (colorimetric method), respectively, and the relevant operations were in accordance with the instructions provided by the manufacturer. All kits were purchased from Nanjing Jiancheng Biological Engineering Company. The absorbance is measured using a microplate reader (Thermo) or an ultraviolet spectrophotometer (Shimadzu, Japan).

\section{Statistical Analysis}

All data were expressed as mean \pm standard deviation (Mean \pm SD). SPSS software (IBM Statistics SPSS 22 for Windows, USA) was used to test the data for normal 
distribution and homogeneity of variance. Analysis of Variance (ANOVA) was performed under the conditions of satisfying the two tests. Differences between groups were analyzed by two-way analysis of variance (two-way ANOVA). An independent sample $t$-test was used for the difference between the two groups of means. $\mathrm{P}<0.05$ was used as the criterion of statistical difference.

\section{Results}

\section{Volatile Compounds of Chilli Pepper}

There are 7 main volatile compounds (2-Methyl-1-tetralone, $\beta$-Elemene, $\beta$-Caryophyllene, Hexanal, Furfural, Nonanal, and 2-methyldecane, Supporting Information Figure S1) with more $15 \% \beta$-Caryophyllene in the chilli pepper (Figure 1A) according to standards (Figure 1B).

\section{SphKI Expression in Lung Cancer from GEPIA2 Database and Interaction with miRNA}

Bodymap shows that the median expression of SphK1 increased in many tumor tissues and reduces in the normal samples (Figure 2A, P $<0.05$ ). SphK1 expression levels increased in lung cancer tissues and reduced in normal tissues (Figure 2B, $\mathrm{P}<0.05$ ). SphK1 expression increased with lung cancer development and reduced at stage IV (Figure $2 \mathrm{C}, \mathrm{P}<0.05$ ). The overall survival time of lung cancer patients based on high-level SphK1 expression was shorter than the low-level expression (Figure 2D, $\mathrm{P}<0.05$ ). miRDB analysis shows that SphK1 was predicted to be targeted by 12 miRNAs and miR-659-3p with the highest target scores (Figure 2E, $\mathrm{P}<0.05$ ). The target site sequence (GAACCAA) at 3' - UTR of SphK1 could be recognized by the sequence of miR-659-3p (CUUGGUU) via complementary binding ability (Figure $2 \mathrm{~F}$ ).

\section{$\beta$-Caryophyllene and miR-659-3p Intervention Inhibited NSCLC Growth}

MTT analysis showed that $\beta$-Caryophyllene had significant inhibitory functions on NSCLC cell lines A549 (Figure 3A, $\mathrm{P}<0.05$ ), NCI-H1299 (Figure 3B, $\mathrm{P}<0.05$ ), HCC827 (Figure 3C, $\mathrm{P}<0.05$ ), and PC9 (Figure 3D, $\mathrm{P}<0.05$ ) after 24-, 48- and 72-h culture. $\beta$ Caryophyllene treatment and miR-659-3p mimic inhibited the growth of NSCLC cell lines A549 (Figure 3E, $\mathrm{P}<0.05$ ), NCI-H1299 (Figure 3F, $\mathrm{P}<0.05$ ), HCC827 (Figure 3G, P < 0.05), and PC9 (Figure 3H, P<0.05) after 24-, 48- and 72-h culture. In contrast, miR-659-3p siRNA promoted the growth of NSCLC cell lines NSCLC cell lines A549 (Figure 3E, P $<0.05$ ), NCIH1299 (Figure 3F, P < 0.05), HCC827 (Figure 3G, $\mathrm{P}<$ 0.05 ), and PC9 (Figure 3H, P $<0.05$ ) after 24-, 48- and $72-\mathrm{h}$ culture. The results suggest that $\beta$-Caryophyllene and miR-659-3p intervention inhibits NSCLC growth. The cells were treated with 10,20 and $40 \mu \mathrm{M}$ of the individual volatiles compound standard. About $40 \mu \mathrm{M}$ of $\beta$-Caryophyllene showed the highest inhibitory effects on NSCLC growth and used in the subsequent experiment.
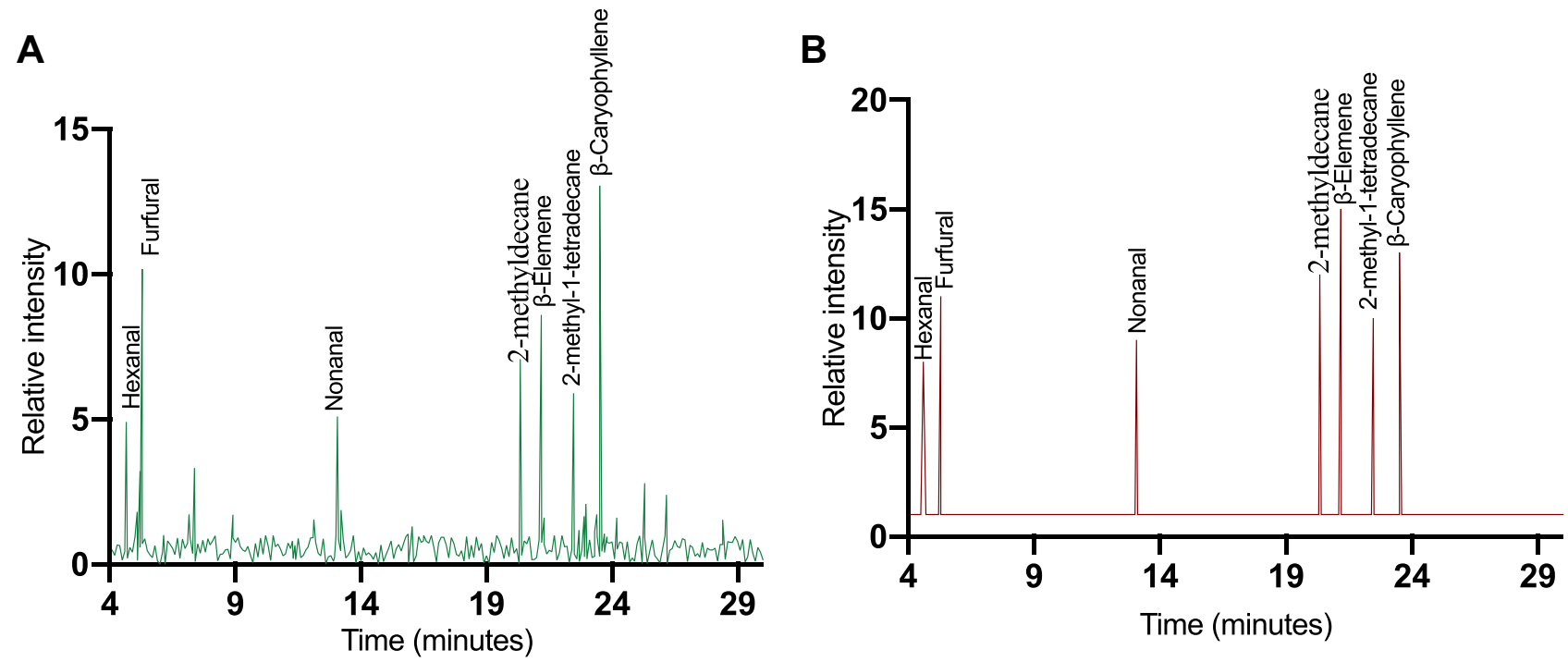

Figure I GC-MS analysis of volatile compounds of chilli pepper and their standards. (A) The main volatile compounds of chilli pepper. (B) The standards of the main compounds (2-Methyl-I-tetralone, $\beta$-Caryophyllene, $\beta$-Elemene, Hexanal, Furfural, Nonanal, and 2-methyldecane). 
A

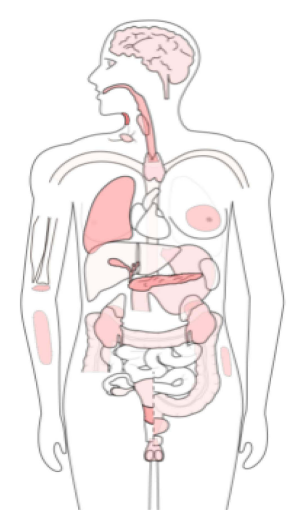

Tumor

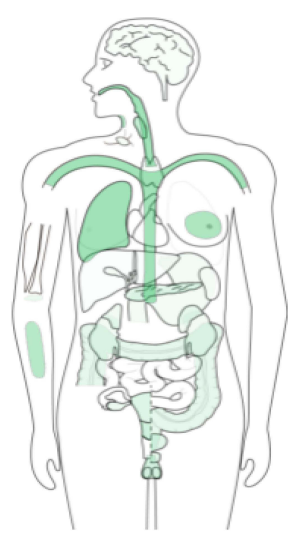

Normal
C
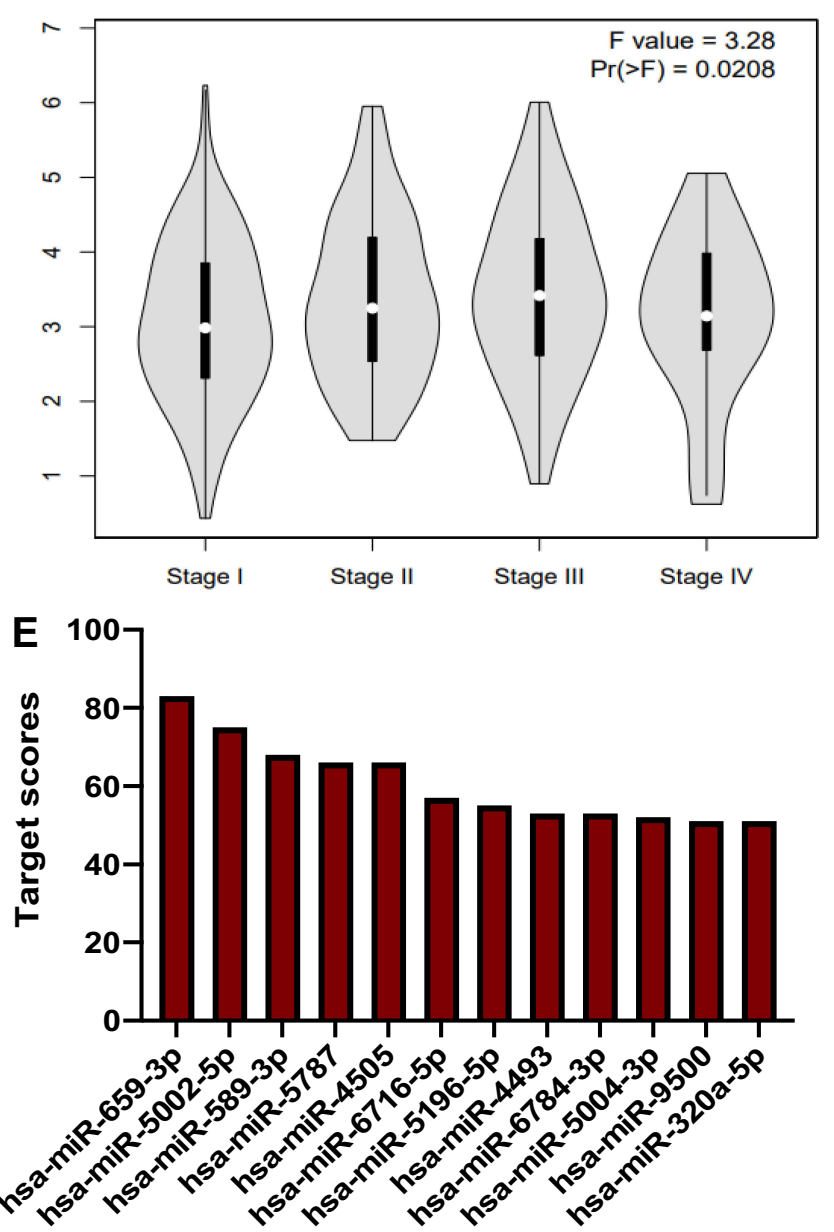

B

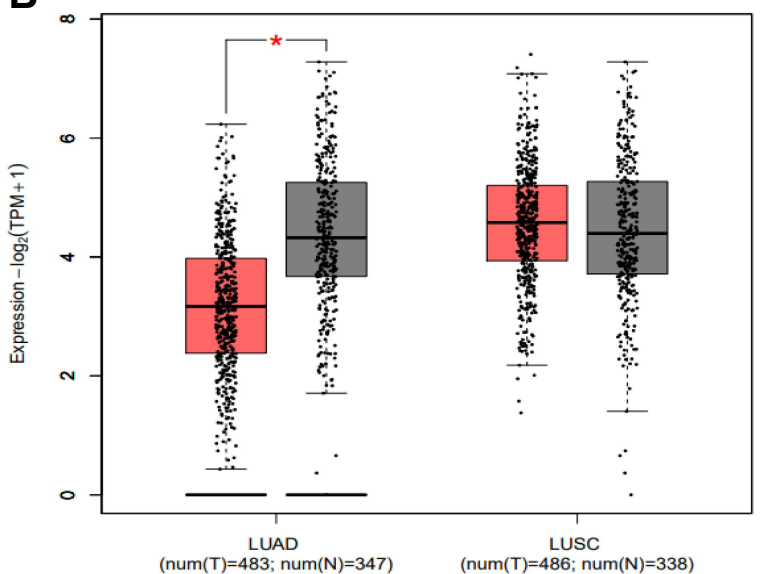

D

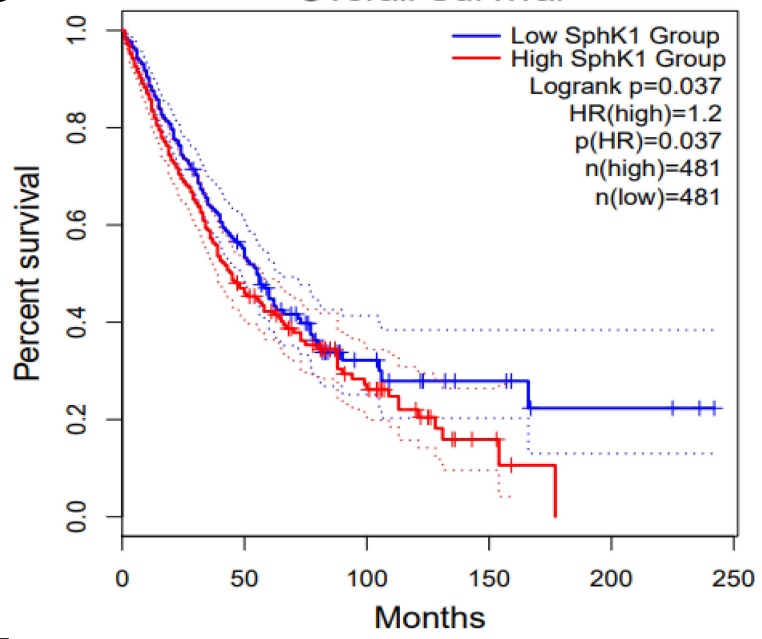

$\mathbf{F}$

\section{3'UTR sequence of SphK1} $\begin{aligned} 1 & \text { cccetgggec gegctgtgcc ttagtgtcta cttgcaggac ccttcctcct tccctagggc } \\ 61 & \text { tgcagggcct gtccacagct cctgtggggg tggaggagac tcctctggag aagggtgaga }\end{aligned}$ 121 aggtggaggc tatgctttgg ggggacaggc cagaatgaag tcctgggtca ggagccagc 181 tggctgggcc cagctgccta tgtaaggcct tctagtttgt tctgagaccc ccaccccacg 241 aaccaaatcc aaataaagtg acattcccag cctgaaaaaa aaaaaaaaa aa

Figure 2 SphKI expression in lung cancer from GEPIA2 database and interaction with miRNA. (A) The median expression of SphKI tumor and normal samples in bodymap. Red represents upregulation and green represents down-regulation. (B) GEPIA2 database was used to obtain the SphKI expression levels in lung cancer and normal tissues. (C) SphKI expression at different stage of lung cancer. (D) Kaplan-Meier analysis of the overall survival of lung cancer patients based on SphKI expression in GEPIA2 database. (E) SphKI is predicted to be targeted by 12 miRNAs in miRDB. (F) Target site analysis between SphKI and miR-659-3p.

Abbreviations: LUAD, lung adenocarcinoma; LUSC, lung squamous cell carcinoma. 
A

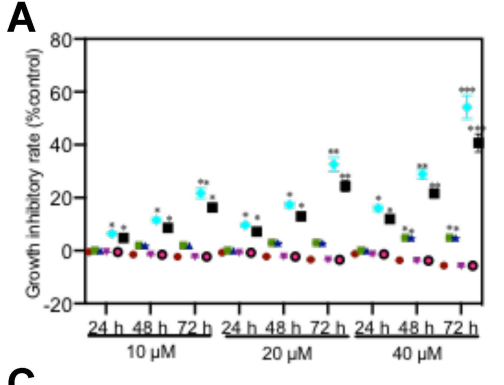

C

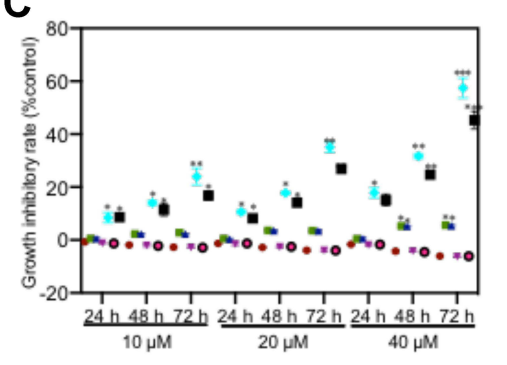

E

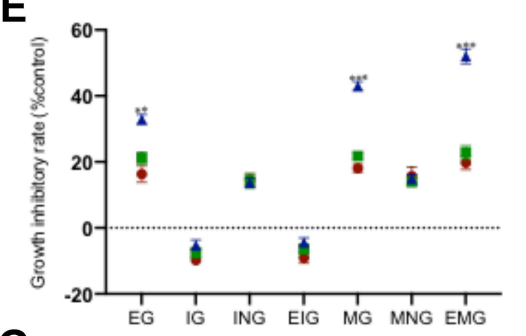

G

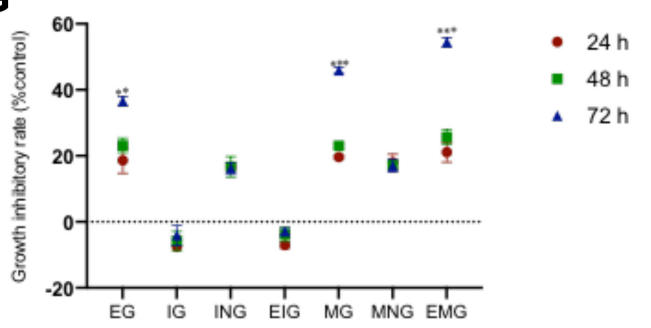

B

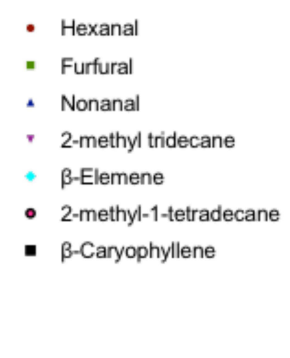

- Hexanal

- Furfural

- Nonanal

- 2-methyl tridecane

$\beta$-Elemene

- 2-methyl-1-tetradecane

- $\beta$-Caryophyllene

- $24 \mathrm{~h}$

- $48 \mathrm{~h}$

A $72 \mathrm{~h}$

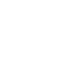

(2)

D
- Hexanal

- Furfural

- Nonanal

- 2-methyl tridecane

- $\beta$-Elemene

- 2-methyl-1-tetradecane

- $\beta$-Caryophyllene
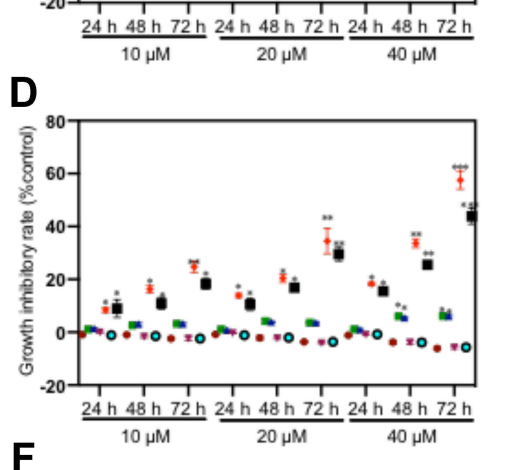

- Hexanal

- Furfural

- Nonanal

- 2-methyl tridecane

- $\beta$-Elemene

- 2-methyl-1-tetradecane

- $\beta$-Caryophyllene

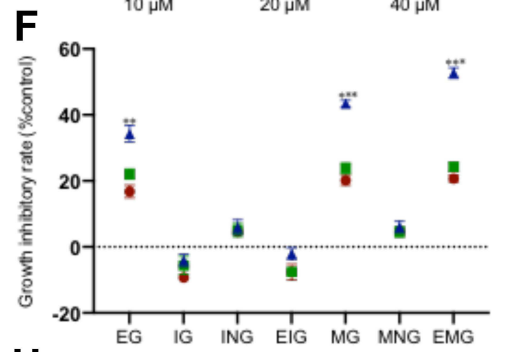

H

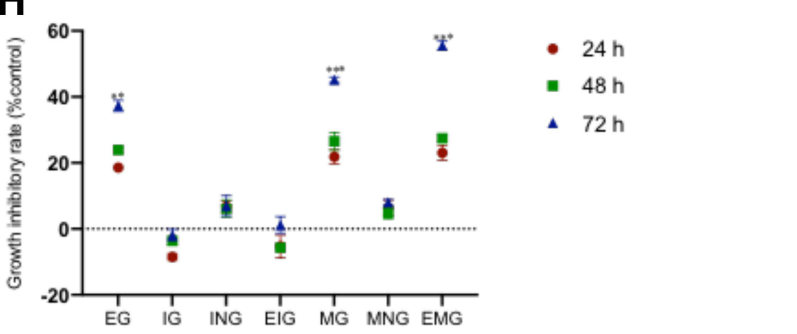

Figure 3 MTT analysis of the effects of $\beta$-Caryophyllene and miR-659-3p on the growth of lung cancer cells. (A) The effects of $\beta$-Caryophyllene on the growth of non-small cell lung cancer (NSCLC) cell lines A549. (B) The effects of $\beta$-Caryophyllene on the growth of NSCLC cell lines NCI-HI299. (C) The effects of miR-659-3p on the growth of NSCLC cell lines A549. (D) The effects of miR-659-3p on the growth of NSCLC cell lines NCl-HI299. (E) The effects of miR-659-3p mimic or siRNA on the growth of NSCLC cell lines A549. (F) The effects of miR-659-3p mimic or siRNA on the growth of NSCLC cell lines NCl-HI299. (G) The effects of miR-659-3p mimic or siRNA on the growth of NSCLC cell lines HCC827. (H) The effects of miR-659-3p mimic or siRNA on the growth of NSCLC cell lines PC9. All experiments were performed in triplicate. $* \mathrm{P}<0.05, * * \mathrm{P}<0.01$ and $* * * \mathrm{P}<0.001$ vs the $\mathrm{CG}$ group.

Abbreviations: CG, control group; EG, $\beta$-Caryophyllene treated group; IG, miR-659-3p siRNA group; ING, miR-659-3p siRNA scrambled group; EIG, $\beta$-Caryophyllene treated miR-659-3p siRNA group; MG, miR-659-3p mimic group; MNG, miR-659-3p mimic scrambled group; EMG, $\beta$-Caryophyllene treated miR-659-3p mimic group.

\section{$\beta$-Caryophyllene Intervention Increased miR-659-3p Level and Apoptotic Factors mRNA Level, and Reduced SphKI mRNA Level}

qRT-PCR analysis showed that $\beta$-Caryophyllene had significant effects on miR-659-3p level in NSCLC cell lines A549 (Figure 4A, P $<0.05$ ) and NCIH1299 after 24-, 48- and 72-h culture (Figure 4B, $\mathrm{P}<0.05)$ among all volatile compounds. Therefore, $\beta$ -
Caryophyllene was selected to explore the possible mechanisms. miR-659-3p siRNA reduced the level of miR-659-3p and the mimic increased the level of miR659-3p in NSCLC cell lines A549 (Figure 4C, P < 0.05 ) and NCI-H1299 after 24-, 48- and 72-h culture (Figure 4D, $\mathrm{P}<0.05$ ), suggesting that miR-659-3p was successfully blocked or over-expressed. In contrast, miR-659-3p siRNA increased the mRNA level of SphK1 and the mimic reduced the mRNA level of SphK1 in NSCLC cell lines A549 (Figure 4E, P < 


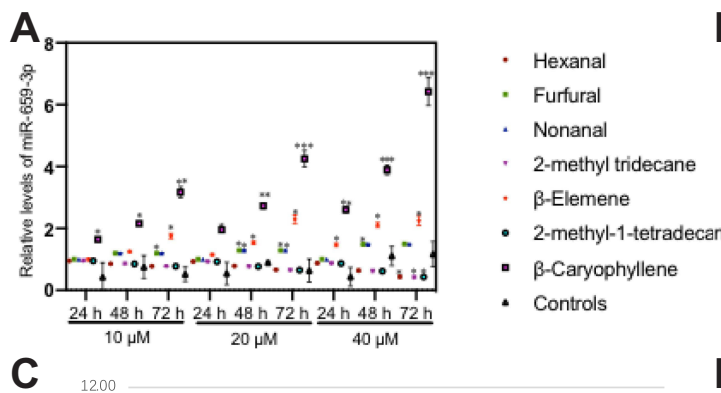

B

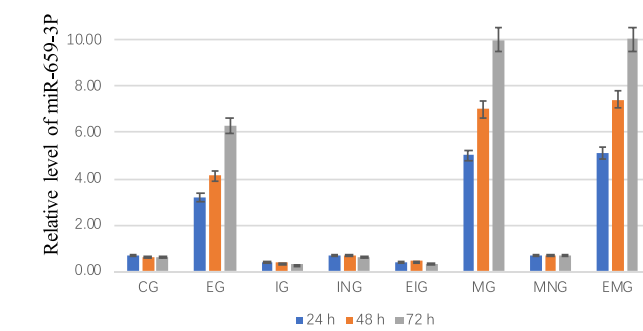

D

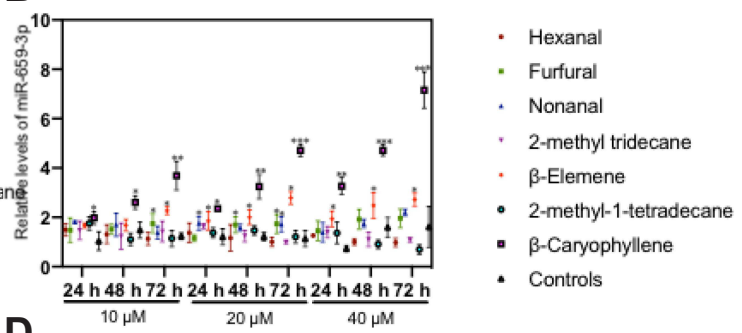

E

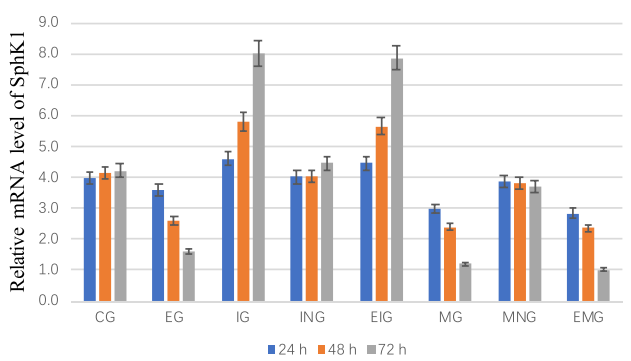

F

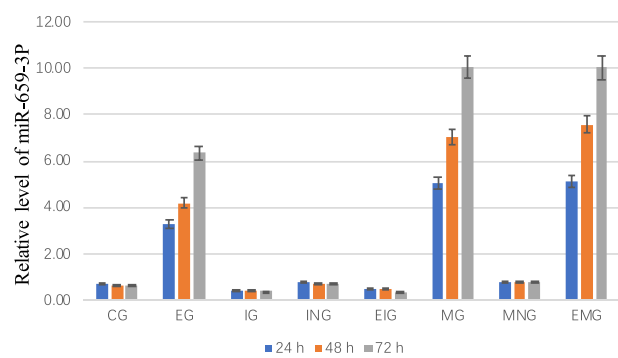

G

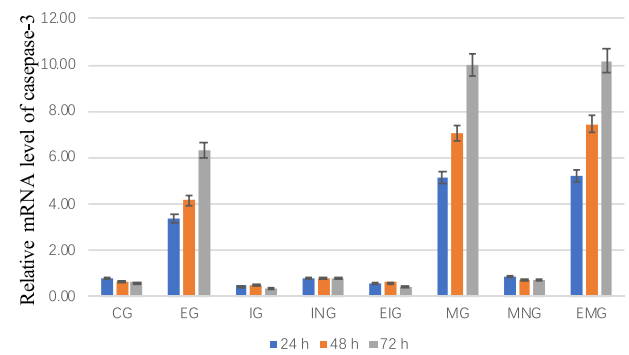

I
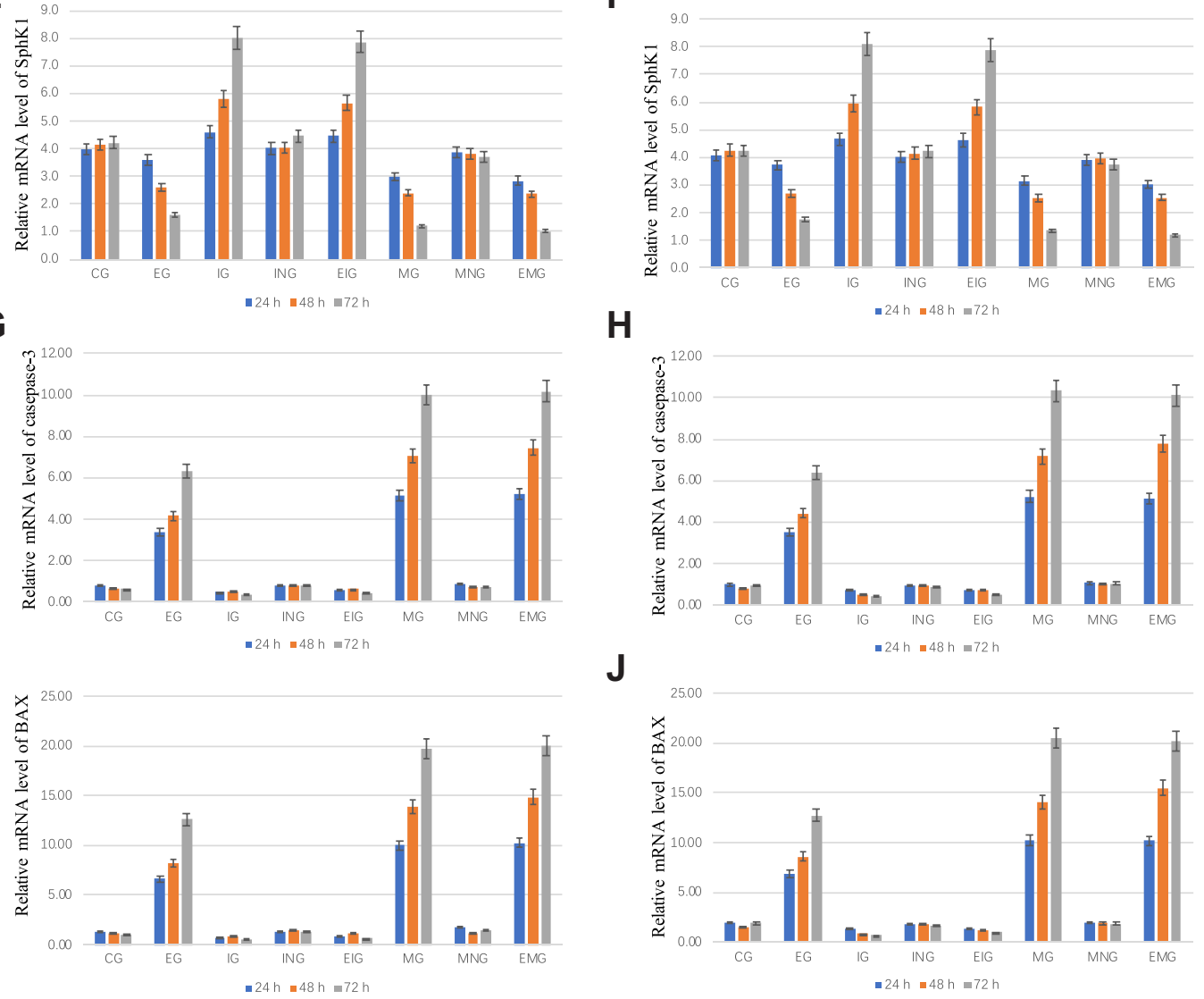

H

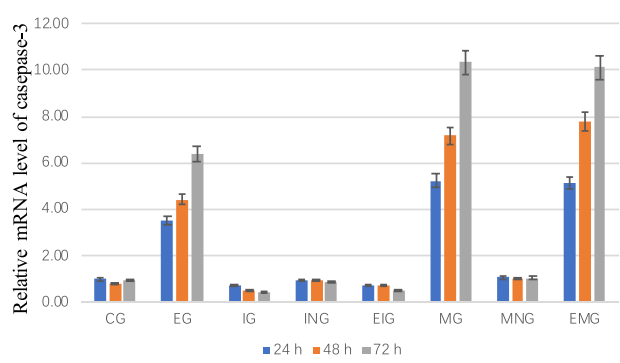

J

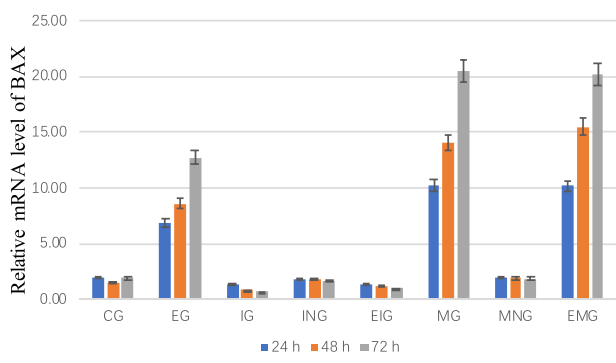

Figure 4 The RNA levels of miR-659-3p/SphKI loop and apoptotic factors. (A) The effects of volatile compounds (Hexanal (A), Furfural (B), Nonanal (C), 2-methyldecane (D), $\beta$-Elemene (E), 2-Methyl-I-tetralone (F), $\beta$-Caryophyllene $(\mathbf{G})$ and controls $(\mathbf{H})$ ) of chilli pepper on miR-659-3p level in NSCLC cell lines A549. (B) The effects of volatile compounds of chilli pepper on miR-659-3p level in NSCLC cell lines NCl-HI299. (C) The effects of miR-659-3p siRNA and mimic, and or $\beta$-Caryophyllene treatment on miR-659-3p level in NSCLC cell lines A549. (D) The effects of miR-659-3p siRNA and mimic, and or $\beta$-Caryophyllene treatment on miR-659-3p level in NSCLC cell lines NCl-HI299. (E) The effects of miR-659-3p siRNA and mimic, and or $\beta$-Caryophyllene treatment on relative mRNA level of SphKI in NSCLC cell lines A549. (F) The effects of miR-659-3p siRNA and mimic, and or $\beta$-Caryophyllene treatment on relative mRNA level of SphKI in NSCLC cell lines NCI-HI299. (G) The effects of miR-659-3p siRNA and mimic, and or $\beta$-Caryophyllene treatment on relative mRNA level of caspase-3 in NSCLC cell lines A549. (H) The effects of miR-659-3p siRNA and mimic, and or $\beta$-Caryophyllene treatment on relative mRNA level of caspase-3 in NSCLC cell lines NCl-HI299. (I) The effects of miR-659-3p siRNA and mimic, and or $\beta$-Caryophyllene treatment on relative mRNA level of BAX in NSCLC cell lines A549. (J) The effects of miR-659-3p siRNA and mimic, and or $\beta$-Caryophyllene treatment on relative mRNA level of BAX in NSCLC cell lines $\mathrm{NCl}-\mathrm{HI} 299.40 \mu \mathrm{M}$ of $\beta$-Caryophyllene showed the highest inhibitory effects on NSCLC growth and used in the subsequent experiment. All experiments were performed in triplicate. $* \mathrm{P}<0.05, * * \mathrm{P}<0.01$ and $* * * \mathrm{P}<0.00 \mathrm{I}$ vs the $\mathrm{CG}$ group. 
0.05) and NCI-H1299 after 24-, 48- and 72-h culture (Figure 4F, $\mathrm{P}<0.05$ ), suggesting that SphK1 was closely targeted by miR-659-3p. miR-659-3p siRNA reduced the mRNA level of caspase- 3 and the mimic increased the mRNA level of caspase- 3 in NSCLC cell lines A549 (Figure 4G, P < 0.05) and NCI-H1299 after 24-, 48- and 72-h culture (Figure $4 \mathrm{H}, \mathrm{P}<0.05$ ). miR659-3p siRNA reduced the mRNA level of BAX and the mimic increased the mRNA level of BAX in NSCLC cell lines A549 (Figure 4I, P < 0.05) and NCIH1299 after 24-, 48- and 72-h culture (Figure 4J, P <
0.05). All these results suggest that miR-659-3p can affect the mRNA levels of apoptotic factors.

\section{$\beta$-Caryophyllene and miR-659-3p Intervention Reduced the Protein Level of SphKI and Increased Relative Protein Levels of Apoptotic Factors}

ELISA analysis showed that $\beta$-Caryophyllene had significant inhibitory effects on SphK1 protein concentration in NSCLC cell lines A549 (Figure 5A, P $<0.05$ ) and NCI-
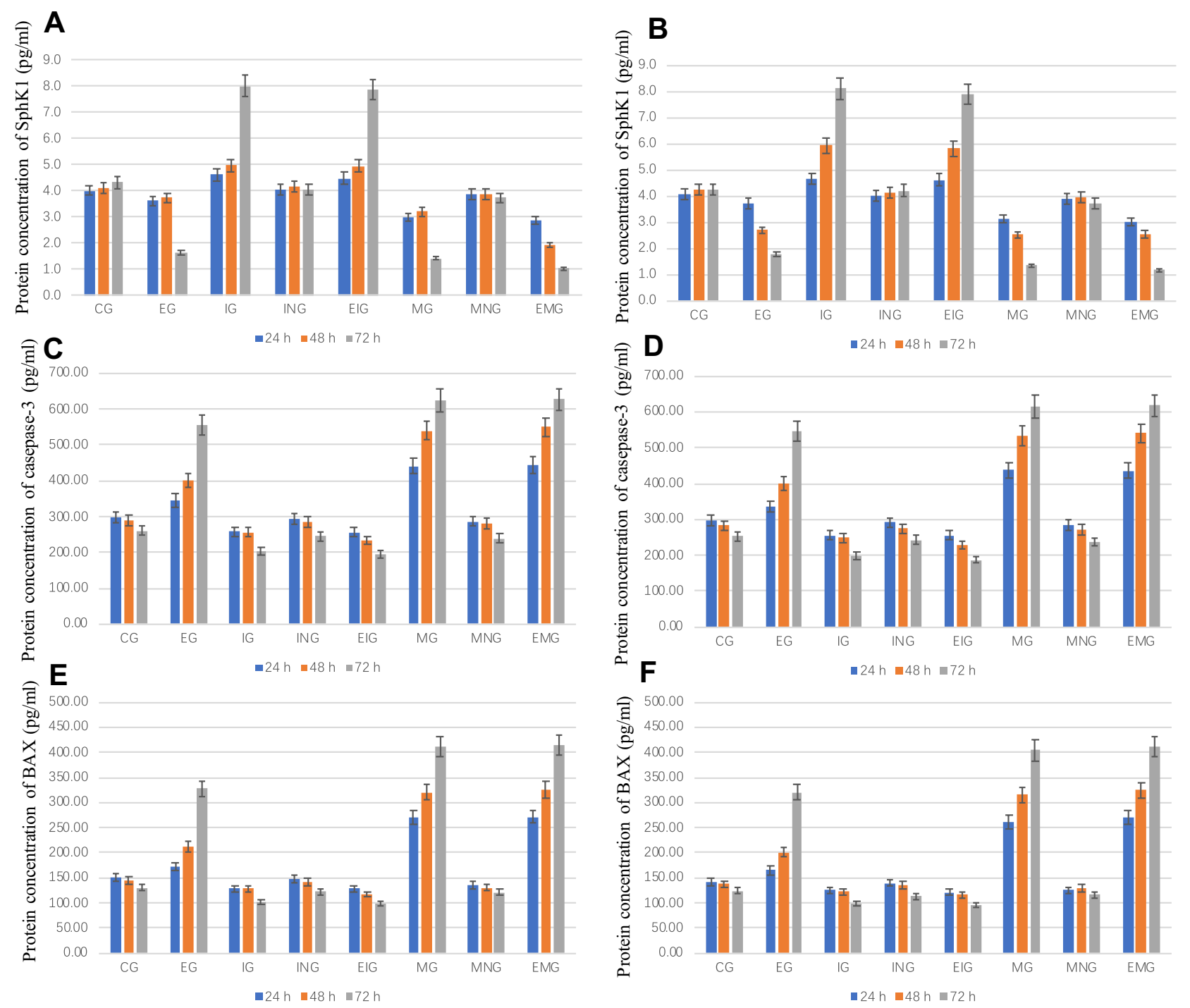

Figure 5 Protein concentration of SphKI and apoptotic factors. (A) The effects of miR-659-3p siRNA and mimic, and or $\beta$-Caryophyllene treatment on protein concentration of SphKI in NSCLC cell lines A549. (B) The effects of miR-659-3p siRNA and mimic, and or $\beta$-Caryophyllene treatment on protein concentration of SphKI in NSCLC cell lines NCl-HI299. (C) The effects of miR-659-3p siRNA and mimic, and or $\beta$-Caryophyllene treatment on protein concentration of cleaved caspase-3 in NSCLC cell lines A549. (D) The effects of miR-659-3p siRNA and mimic, and or $\beta$-Caryophyllene treatment on protein concentration of cleaved caspase-3 in NSCLC cell lines NCl-HI299. (E) The effects of miR-659-3p siRNA and mimic, and or $\beta$-Caryophyllene treatment on protein concentration of BAX in NSCLC cell lines A549. (F) The effects of miR-659-3p siRNA and mimic, and or $\beta$-Caryophyllene treatment on protein concentration of BAX in NSCLC cell lines NCl-HI299. $40 \mu \mathrm{M}$ of $\beta$-Caryophyllene showed the highest inhibitory effects on NSCLC growth and used in the subsequent experiment. All experiments were performed in triplicate. 
H1299 after 24-, 48- and 72-h culture (Figure 5B, $\mathrm{P}<$ 0.05). Similarly, miR-659-3p siRNA increased the protein level of SphK1 and the mimic reduced the protein level of SphK1 in NSCLC cell lines A549 (Figure 5A, P < 0.05) and NCI-H1299 after 24-, 48- and 72-h culture (Figure 5B, $\mathrm{P}<0.05$ ), suggesting that SphK1 was closely targeted by miR-659-3p. $\beta$-Caryophyllene had significant promoting effects on cleaved caspase-3 protein concentration in NSCLC cell lines A549 (Figure 5C, P < 0.05) and NCIH1299 after 24-, 48- and 72-h culture (Figure 5D, P < 0.05). miR-659-3p siRNA reduced the protein level of cleaved caspase- 3 and the mimic increased the protein level of cleaved caspase- 3 in NSCLC cell lines A549 (Figure 5C, P < 0.05) and NCI-H1299 after 24-, 48- and 72-h culture (Figure 5D, $\mathrm{P}<0.05$ ). Caryophyllene had significant promoting effects on BAX protein concentration in NSCLC cell lines A549 (Figure 5E, P < 0.05) and NCI-H1299 after 24-, 48- and 72-h culture (Figure 5F, P < 0.05). miR-659-3p siRNA reduced the protein level of $\mathrm{BAX}$ and the mimic increased the protein level of BAX in NSCLC cell lines A549 (Figure 5E, P < 0.05) and NCIH1299 after 24-, 48- and 72-h culture (Figure 5F, $\mathrm{P}<$ $0.05)$. $\beta$-Caryophyllene and miR-659-3p intervention may promote NSCLC apoptosis via SphK1.

\section{$\beta$-Caryophyllene and miR-659-3p Intervention Reduced Oxidative Stress and Increased Antioxidant Level of NSCLC}

$\beta$-Caryophyllene had significant inhibitory effects on ROS levels in NSCLC cell lines A549 (Figure 6A, P < 0.05) and NCI-H1299 after 24-, 48- and 72-h culture (Figure 6B, $\mathrm{P}<0.05)$. $\beta$-Caryophyllene also had significant inhibitory effects on NO level in NSCLC cell lines A549 (Figure 6C, $\mathrm{P}<0.05)$ and NCI-H1299 after 24-, 48- and 72-h culture (Figure 6D, $\mathrm{P}<0.05$ ). miR-659-3p siRNA increased the ROS level and the mimic reduced ROS level in NSCLC cell lines A549 (Figure 6A, P < 0.05) and NCI-H1299 after 24-, 48- and 72-h culture (Figure 6B, $\mathrm{P}<0.05$ ). miR659-3p siRNA increased the NO level and the mimic reduced NO level in NSCLC cell lines A549 (Figure 6C, $\mathrm{P}<0.05)$ and NCI-H1299 after 24-, 48- and 72-h culture (Figure 6D, $\mathrm{P}<0.05$ ). The results suggest that $\beta$ Caryophyllene and miR-659-3p intervention reduce oxidative stress in the NSCLC.
$\beta$-Caryophyllene had significant promoting effects on SOD activity in NSCLC cell lines A549 (Figure 6E, P < $0.05)$ and NCI-H1299 after 24-, 48- and 72-h culture (Figure 6F, $\mathrm{P}<0.05$ ). $\beta$-Caryophyllene had significant promoting effects on CAT level in NSCLC cell lines A549 (Figure 6G, P < 0.05) and NCI-H1299 after 24-, 48- and 72-h culture (Figure 6H, $\mathrm{P}<0.05$ ). $\beta$ Caryophyllene also had significant promoting effects on GPx level in NSCLC cell lines A549 (Figure 6I, P < 0.05) and NCI-H1299 after 24-, 48- and 72-h culture (Figure 6J, $\mathrm{P}<0.05)$. miR-659-3p siRNA reduced the SOD activity and the mimic increased SOD activity in NSCLC cell lines A549 (Figure 6E, P < 0.05) and NCI-H1299 after 24-, 48and $72-\mathrm{h}$ culture (Figure $6 \mathrm{~F}, \mathrm{P}<0.05$ ). miR-659-3p siRNA reduced the CAT activity and the mimic increased CAT activity in NSCLC cell lines A549 (Figure 6G, P < 0.05) and NCI-H1299 after 24-, 48- and 72-h culture (Figure $6 \mathrm{H}, \mathrm{P}<0.05$ ). miR-659-3p siRNA also reduced the GPx activity and the mimic increased GPx activity in NSCLC cell lines A549 (Figure 6I, P < 0.05) and NCIH1299 after 24-, 48- and 72-h culture (Figure 6J, P < $0.05)$. The results suggest that $\beta$-Caryophyllene and miR659-3p intervention increases antioxidant properties in the NSCLC.

\section{$\beta$-Caryophyllene and miR-659-3p Intervention Induced NSCLC Apoptosis}

$\beta$-Caryophyllene had significant inhibitory effects on the apoptotic level in NSCLC cell lines A549 (Figure 7A and 7B, $\mathrm{P}<0.05)$ and NCI-H1299 after 72-h culture (Figure 7C and 7D, $\mathrm{P}<0.05$ ). miR-659-3p siRNA reduced the apoptotic rate level and the mimic increased apoptotic rate in NSCLC cell lines A549 (Figure 7A and 7B, P < 0.05 ) and NCI-H1299 after 72-h culture (Figure 7C and $7 \mathrm{D}, \mathrm{P}<0.05)$. All these results suggest that $\beta$ Caryophyllene and miR-659-3p intervention promoted NSCLC apoptosis.

\section{Discussion}

Natural product intervention is one of the crucial approaches to reduce or delay the occurrence of NSCLC. ${ }^{31-33}$ The potential value of this approach has been demonstrated with trials in breast, ${ }^{34,35}$ prostate, ${ }^{36,37}$ and colon cancer. ${ }^{36,37}$ Because of low cytotoxicity to normal cells, minimal side effects, and a wide margin of safety, natural products can be used to develop new pharmaceutical drugs. 
A
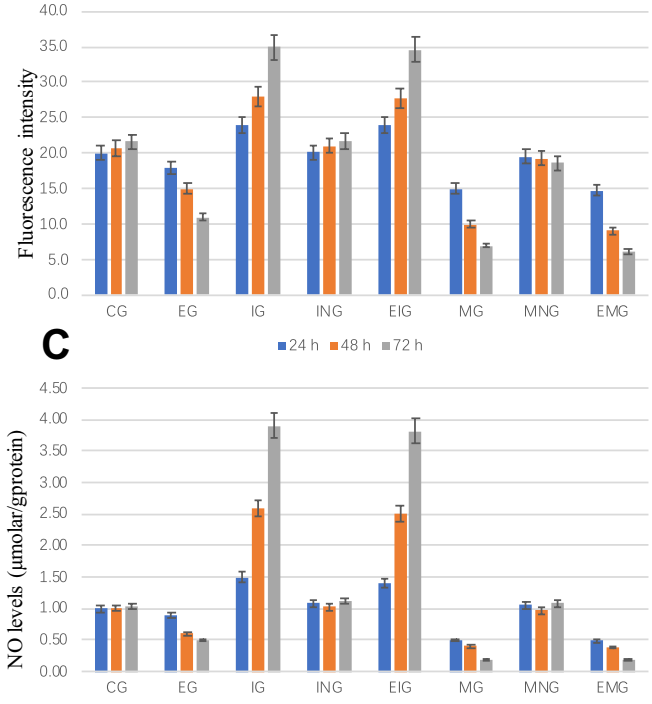

E
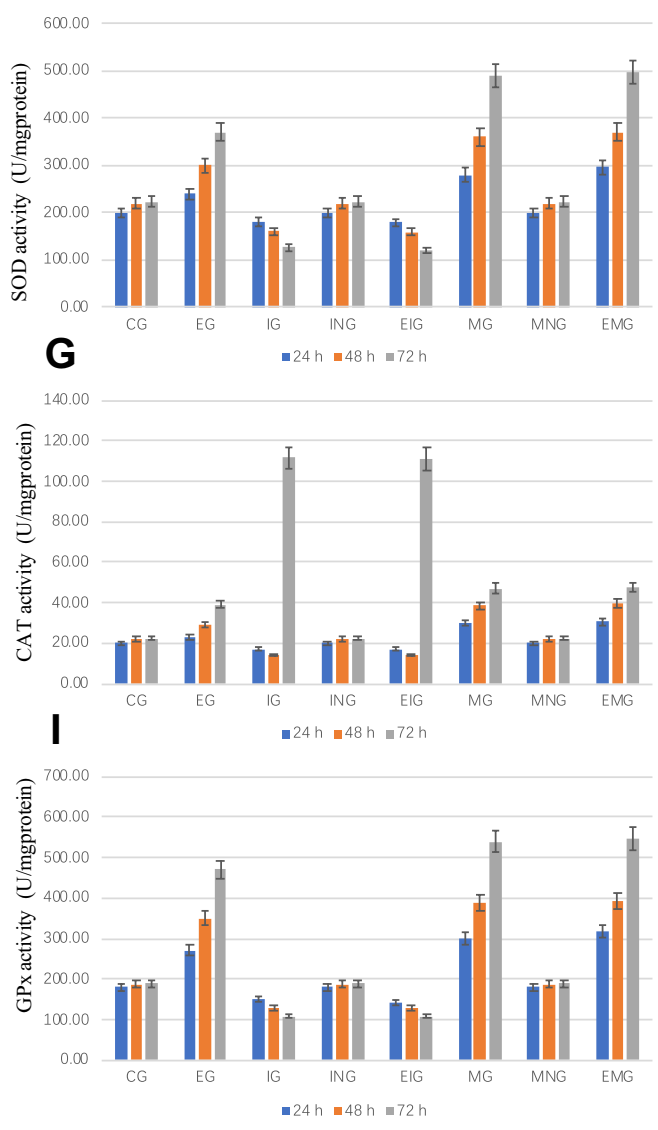

B
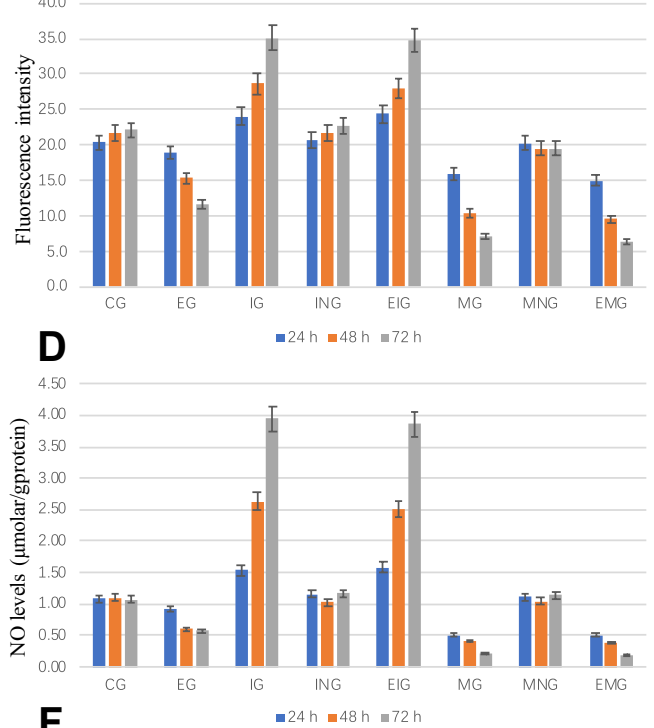

$\mathbf{F}$
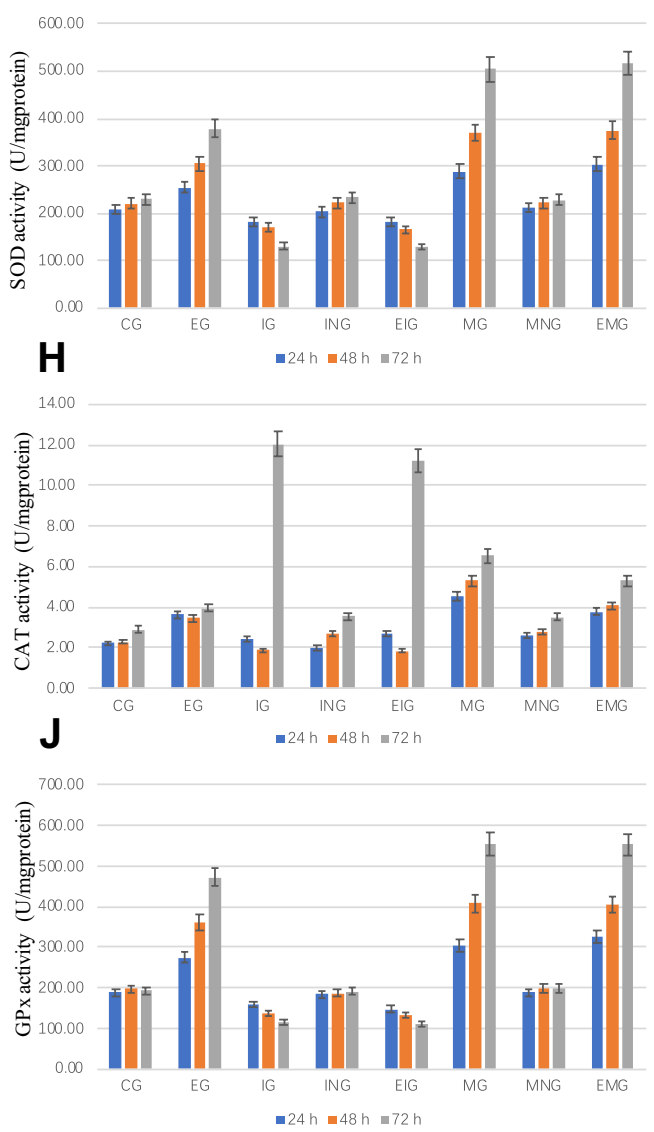

Figure 6 The effects of miR-659-3p siRNA and mimic, and or $\beta$-Caryophyllene treatment on the levels of oxidative stress and antioxidants in NSCLC cells. (A) The effects of miR-659-3p siRNA and mimic, and or $\beta$-Caryophyllene treatment on ROS level in NSCLC cell lines A549. (B) The effects of miR-659-3p siRNA and mimic, and or $\beta$ Caryophyllene treatment on ROS level in NSCLC cell lines NCl-HI299. (C) The effects of miR-659-3p siRNA and mimic, and or $\beta$-Caryophyllene treatment on NO level in NSCLC cell lines A549. (D) The effects of miR-659-3p siRNA and mimic, and or $\beta$-Caryophyllene treatment on NO level in NSCLC cell lines NCl-HI299. (E) The effects of miR-659-3p siRNA and mimic, and or $\beta$-Caryophyllene treatment on SOD activity in NSCLC cell lines A549. (F) The effects of miR-659-3p siRNA and mimic, and or $\beta$ Caryophyllene treatment on SOD activity in NSCLC cell lines NCl-HI299. (G) The effects of miR-659-3p siRNA and mimic, and or $\beta$-Caryophyllene treatment on CAT activity in NSCLC cell lines A549. (H) The effects of miR-659-3p siRNA and mimic, and or $\beta$-Caryophyllene treatment on CAT activity in NSCLC cell lines NCI-HI299. (I) The effects of miR-659-3p siRNA and mimic, and or $\beta$-Caryophyllene treatment on GPx activity in NSCLC cell lines A549. (J) The effects of miR-659-3p siRNA and mimic, and or $\beta$-Caryophyllene treatment on GPx activity in NSCLC cell lines NCl-HI299. $40 \mu \mathrm{M}$ of $\beta$-Caryophyllene showed the highest inhibitory effects on NSCLC growth and used in the subsequent experiment. All experiments were performed in triplicate. 
A
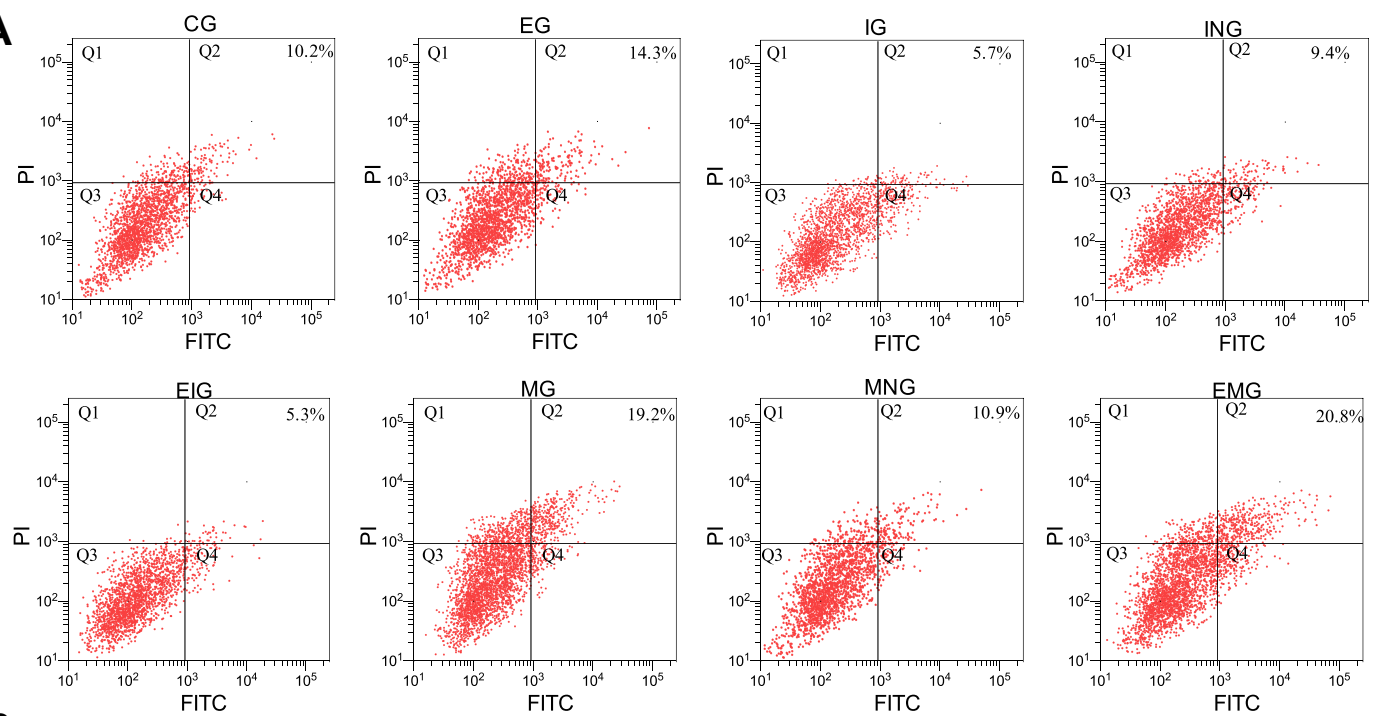

B

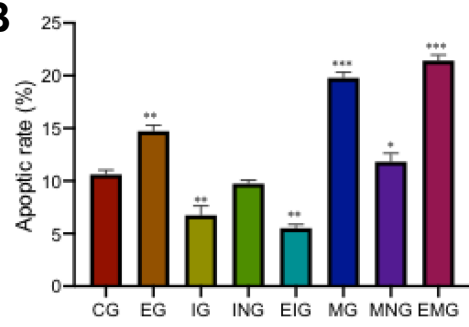

C
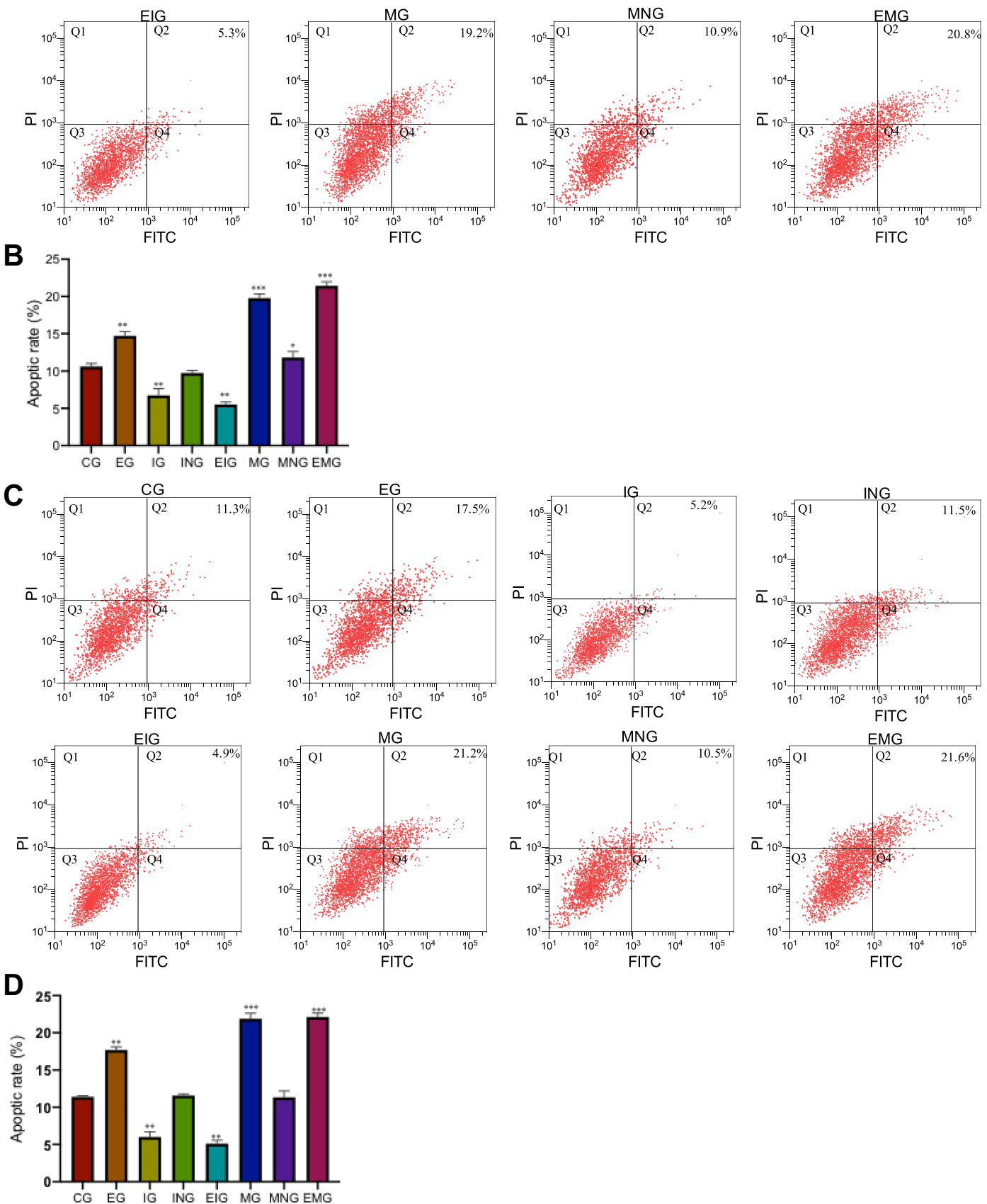
Figure 7 The effects of miR-659-3p siRNA and mimic, and or $\beta$-Caryophyllene treatment on the apoptotic levels in NSCLC cells. (A) The effects of miR-659-3p siRNA and
mimic, and or $\beta$-Caryophyllene treatment on apoptotic levels in NSCLC cell lines A549. (B) Different apoptotic levels among different groups in NSCLC cell lines A549. (C) The effects of miR-659-3p siRNA and mimic, and or $\beta$-Caryophyllene treatment on apoptotic levels in NSCLC cell lines NCl-HI299. $40 \mu \mathrm{M}$ of $\beta$-Caryophyllene showed the highest inhibitory effects on NSCLC growth and used in the subsequent experiment. (D) Different apoptotic levels among different groups in NSCLC cell lines NCl-HI299. All experiments were performed in triplicate. $* \mathrm{P}<0.05$, $* * \mathrm{P}<0.0 \mathrm{I}$ and $* * * \mathrm{P}<0.00 \mathrm{I}$ vs the $\mathrm{CG}$ group.

Abbreviations: CG, control group; EG, $\beta$-Caryophyllene treated group; IG, miR-659-3p siRNA group; ING, miR-659-3p siRNA scrambled group; EIG, $\beta$-Caryophyllene treated miR-659-3p siRNA group; MG, miR-659-3p mimic group; MNG, miR-659-3p mimic scrambled group; EMG, $\beta$-Caryophyllene treated miR-659-3p mimic group. 


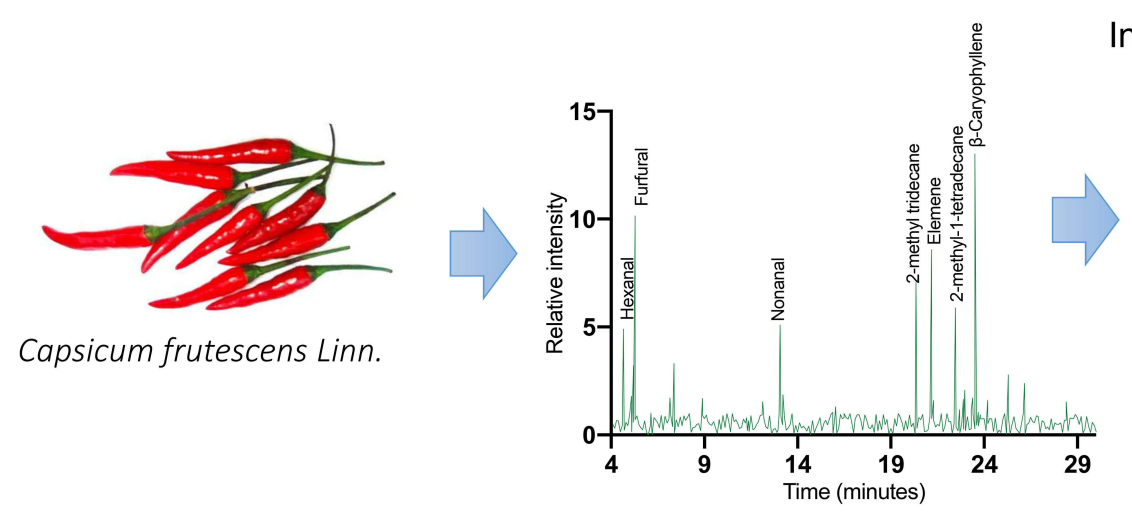

Inhibition rate on lung cancer cells
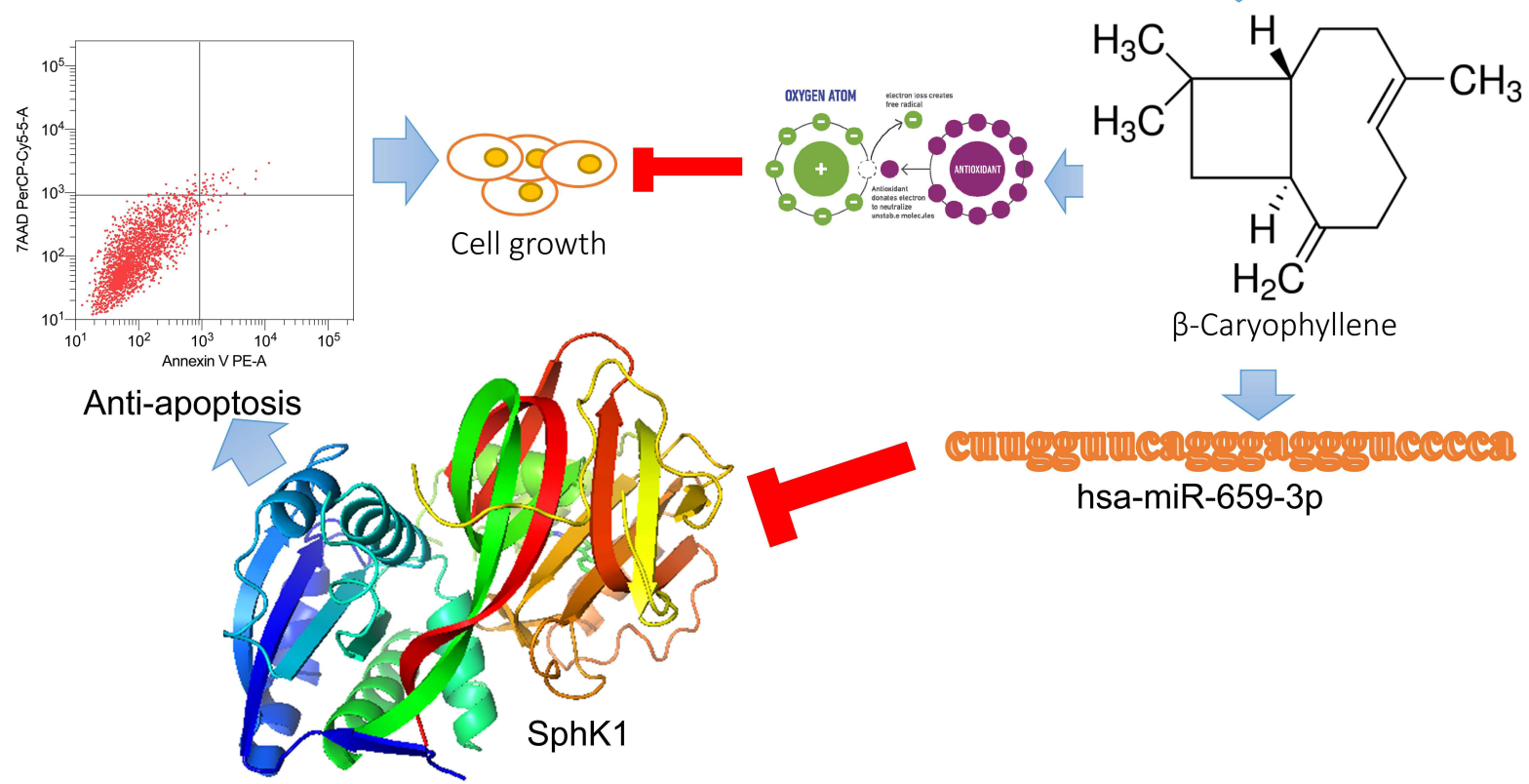

Figure 8 The molecular mechanism for $\beta$-Elemene from chilli pepper inhibiting the proliferation of non-small cell lung cancer cells by affecting miR-659-3p-targeted SphKI and antioxidant properties.

The present findings show that $\beta$-Caryophyllene is the main ingredient of volatile compounds of Chilli pepper and had significant inhibitory effects on NSCLC growth (Figure 3). Furthermore, $\beta$-Caryophyllene treatment reduces the oxidative stress level and increases antioxidant activities and apoptotic factor level (Figures 4-7). miR-659-3p mimic and siRNA prevented and induced the growth of NSCLC cells, their apoptosis, and these biochemical indices. On the other side, $\beta$-Caryophyllene intervention increases the level of miR-659-3p and reduces the level of SphK1. Bioinformatic analysis shows SphK1 may be targeted by miR-659-3p, which is also consistent with the previous report. ${ }^{38} \mathrm{SphK} 1$ has also been reported to inhibit apoptosis in gastric cancer cells by downregulating Bim via the upregulation of Akt/forkhead box O3a (FoxO3a) signaling. ${ }^{39}$ Therefore, $\beta$-caryophyllene from volatile compounds of chilli pepper exerts inhibitory activity in NSCLC cells possibly by affecting miR-659-3p-targeted SphK1 and increasing antioxidant properties (Figure 8).

High-level reactive species including ROS are the main products produced as a consequence of high-level metabolic reactions in the mitochondria of cancers. ${ }^{40}$ Therefore, the antioxidant may be a potential approach for cancer therapy. ${ }^{41}$ The present experiment approves that $\beta$-Caryophyllene increases antioxidant properties in NSCLC and reduces oxidative stress, which is also consistent with the reported work. ${ }^{42}$ However, antioxidant inhibitors have been reported to be used in cancer therapy, ${ }^{43}$ suggesting there are still other mechanisms for the differences.

Our results indicated that $\beta$-caryophyllene induces NSCLC apoptosis. $\beta$-Caryophyllene oxide has been reported 
to prevent tumor growth and induces apoptosis through the suppression of Phosphatidylinositol-3-kinase (PI3K)/AKT/ mammalian target of the rapamycin (mTOR)/S6 Kinase 1 (S6K1) pathways and ROS-mediated mitogen-activated protein kinases (MAPKs) activation. ${ }^{44}$ However, the $\beta$ caryophyllene on NSCLC apoptosis is still seldom reported. Previous work also suggests that $\beta$-caryophyllene may induce cell cycle arrest and lead to apoptosis. ${ }^{45}$

There are some limitations to the present work. We have separated different fractions from chilli pepper. Unfortunately, the purity of some ingredients was less than $90 \%$. To avoid the interference of other ingredients, only the standard samples from a commercial company were used. We have not tried other purified commercial sources either. The present study indicated that $\beta$-caryophyllene in the volatile compounds of chilli pepper may display its antiproliferative effect via in miR-659-3p-targeted SphK1 in NSCLC. The present data suggest that $\beta$-caryophyllene of chilli pepper should be considered as potential natural product in the prevention of NSCLC. To obtain clear conclusion, further work is needed to be done in the future since the present work is only carried out at cellular level.

\section{Acknowledgment}

The present work is supported by the Natural Science Foundation of Heilongjiang Province (Grant NO. LH2019H072).

\section{Disclosure}

The authors declare no conflict of interest.

\section{References}

1. Martín-Sánchez JC, Lunet N, Gonzalez-Marron A, et al. Projections in breast and lung cancer mortality among women: a Bayesian analysis of 52 countries worldwide. Cancer Res. 2018;78(15):4436-4442. doi:10.1158/0008-5472.CAN-18-0187

2. Mao Z, Xu B, He L, Zhang G. PVT1 promotes angiogenesis by regulating miR-29c/vascular endothelial growth factor (VEGF) signaling pathway in non-small-cell lung cancer (NSCLC). Med Sci Monitor. 2019;25:5418. doi:10.12659/MSM.917601

3. Xia Q, Chen G, Ren Y, et al. Investigating efficacy of "microbiota modulation of the gut-lung Axis" combined with chemotherapy in patients with advanced NSCLC: study protocol for a multicenter, prospective, double blind, placebo controlled, randomized trial. $B M C$ Cancer. 2021;21(1):721. doi:10.1186/s12885-021-08448-6

4. Mao S, Zhou F, Liu Y, et al. ICI plus chemotherapy prolonged survival over ICI alone in patients with previously treated advanced NSCLC. Cancer Immunol Immunother. 2021. doi:10.1007/s00262-021-02974-9

5. Lau SCM, Poletes C, Le LW, et al. Durability of CNS disease control in NSCLC patients with brain metastases treated with immune checkpoint inhibitors plus cranial radiotherapy. Lung Cancer. 2021;156:76-81. doi:10.1016/j.lungcan.2021.04.006
6. Tang C, Mistry H, Bayman N, et al. Outcomes of curative-intent radiotherapy in non-small cell lung cancer (NSCLC) patients with chronic obstructive pulmonary disease (COPD) and interstitial lung disease (ILD). Radiother Oncol. 2021;160:78-81. doi:10.1016/j. radonc.2021.04.014

7. Jia $\mathrm{B}$, Zheng Q, Wang J, et al. A nomogram model to predict death rate among non-small cell lung cancer (NSCLC) patients with surgery in surveillance, epidemiology, and end results (SEER) database. BMC Cancer. 2020;20(1):666. doi:10.1186/s12885-020-07147-y

8. Shang $\mathrm{X}, \mathrm{Yu} \mathrm{H}$, Lin J, et al. A Novel Nomogram including AJCC Stages Could Better Predict Survival for NSCLC Patients Who Underwent Surgery: a Large Population-Based Study. J Oncol. 2020;2020:7863984. doi:10.1155/2020/7863984

9. Luo W, Wang Z, Tian P, Li W. Safety and tolerability of PD-1/PD-L1 inhibitors in the treatment of non-small cell lung cancer: a meta-analysis of randomized controlled trials. J Cancer Res Clin Oncol. 2018;144(10):1851-1859. doi:10.1007/s00432-018-2707-4

10. Chung KS, Hong JY, Lee JH, et al. beta-Caryophyllene in the Essential Oil from Chrysanthemum Boreale Induces G1 Phase Cell Cycle Arrest in Human Lung Cancer Cells. Molecules. 2019;24 (20):3754. doi:10.3390/molecules24203754

11. Don ORA, Ahi PA, Kabaran FA, Ziao N. Determination of the Chemical Volatile Compounds of a Chili Pepper Cultivar (Capsicum Annuum) Grown in Eastern Côte d'Ivoire. Asian J App Sci. 2019;7(3). doi:10.24203/ajas.v7i3.5870

12. Chamikara M, Dissanayake D, Ishan M, Sooriyapathirana S. Dietary, anticancer and medicinal properties of the phytochemicals in chili pepper (Capsicum spp.). Ceylon J Sci. 2016;45(3):5. doi:10.4038/cjs. v45i3.7396

13. Lee IO, Lee KH, Pyo JH, Kim JH, Choi YJ, Lee YC. Antiinflammatory effect of capsaicin in Helicobacter pylori-infected gastric epithelial cells. Helicobacter. 2007;12(5):510-517. doi:10.1111/ j.1523-5378.2007.00521.x

14. Genzel F, Dicke MD, Junker-Frohn LV, et al. Impact of Moderate Cold and Salt Stress on the Accumulation of Antioxidant Flavonoids in the Leaves of Two Capsicum Cultivars. J Agric Food Chem. 2021;69(23):6431-6443. doi:10.1021/acs.jafc. 1 c00908

15. Khan N, Ahmed MJ, Shah SZA. 33. Comparative analysis of mineral content and proximate composition from chilli pepper (Capsicum annuum L.) germplasm. Pure App Biol. 2019;8(2):1338-1347.

16. Myszka K, Schmidt MT, Majcher M, Juzwa W, Czaczyk K. $\beta$ Caryophyllene-rich pepper essential oils suppress spoilage activity of Pseudomonas fluorescens KM06 in fresh-cut lettuce. Food Sci Tech. 2017;83:118-126. doi:10.1016/j.1wt.2017.05.012

17. Junior SB, Tavares AM, Teixeira Filho J, Zini CA, Godoy HT. Analysis of the volatile compounds of Brazilian chilli peppers (Capsicum spp.) at two stages of maturity by solid phase micro-extraction and gas chromatography-mass spectrometry. Food Res Inte. 2012;48(1):98-107. doi:10.1016/j.foodres.20 12.02 .005

18. Hasakova K, Bezakova J, Vician M, Reis R, Zeman M, Herichova I. Gender-dependent expression of leading and passenger strand of miR-21 and miR-16 in human colorectal cancer and adjacent colonic tissues. Physiol Res. 2017;2:66.

19. Wang H, Sui ZL, Wu XX, Tang P, Zhang HD, Yu ZT. Reversal of Chemotherapy Resistance to Cisplatin in NSCLC by miRNA-195-5p via Targeting the FGF2 Gene. Pharmgenomics Pers Med. 2021;14:497-508. doi:10.2147/PGPM.S302755

20. Zhang ZY, Gao XH, Ma MY, Zhao CL, Zhang YL, Guo SS. CircRNA_101237 promotes NSCLC progression via the miRNA-490-3p/MAPK1 axis. Sci Rep. 2020;10(1):9024. doi:10.1038/s41598-020-65920-2

21. Larzabal L, de Aberasturi AL, Redrado M, et al. TMPRSS4 regulates levels of integrin alpha5 in NSCLC through miR-205 activity to promote metastasis. $\mathrm{Br} \quad J$ Cancer. 2014;110(3):764-774. doi:10.1038/bjc.2013.761 
22. Song L, Li D, Gu Y, et al. MicroRNA-126 Targeting PIK3R2 Inhibits NSCLC A549 Cell Proliferation, Migration, and Invasion by Regulation of PTEN/PI3K/AKT Pathway. Clin Lung Cancer. 2016;17(5):e65-e75. doi:10.1016/j.cllc.2016.03.012

23. Xiong K, Shao LH, Zhang HQ, et al. MicroRNA-9 functions as a tumor suppressor and enhances radio-sensitivity in radio-resistant A549 cells by targeting neuropilin 1. Oncol Lett. 2018;15 (3):2863-2870. doi:10.3892/ol.2017.7705

24. Liu Z, He C, Qu Y, Chen X, Zhu H, Xiang B. MiR-659-3p regulates the progression of chronic myeloid leukemia by targeting SPHK1. Int J Clin Exp Pathol. 2018;11(5):2470.

25. Francomano F, Caruso A, Barbarossa A, et al. $\beta$-Caryophyllene: a sesquiterpene with countless biological properties. App Sci. 2019;9(24):5420. doi:10.3390/app9245420

26. Chen Y, Wang X. miRDB: an online database for prediction of functional microRNA targets. Nucleic Acids Res. 2020;48(D1): D127-D31. doi:10.1093/nar/gkz757

27. Liu W, Wang X. Prediction of functional microRNA targets by integrative modeling of microRNA binding and target expression data. Genome Biol. 2019;20(1):18. doi:10.1186/s13059-019-1629-z

28. Rubenstein M, Hollowell CM, Guinan P. Inhibition of bcl-2 by antisense oligonucleotides is followed by a compensatory suppression of caspase-3 in LNCaP cells. Eur J Clin Med Oncol. 2011;3(2):1.

29. Liu Z, He C, Qu Y, Chen X, Zhu H, Xiang B. MiR-659-3p regulates the progression of chronic myeloid leukemia by targeting SPHK1. Int J Clin Exp Pathol. 2018;11(5):2470-2478.

30. Jen C-P, Hsiao J-H, Maslov NA. Single-cell chemical lysis on microfluidic chips with arrays of microwells. Sensors. 2012;12(1):347-358 doi:10.3390/s120100347

31. Yao C, Su L, Zhang F, et al. Thevebioside, the active ingredient of traditional Chinese medicine, promotes ubiquitin-mediated SRC-3 degradation to induce NSCLC cells apoptosis. Cancer Lett. 2020;493:167-177. doi:10.1016/j.canlet.2020.08.011

32. Yang J, Zhu X, Yuan P, Liu J, Wang B, Wang G. Efficacy of traditional Chinese Medicine combined with chemotherapy in patients with non-small cell lung cancer (NSCLC): a meta-analysis of randomized clinical trials. Support Care Cancer. 2020;28 (8):3571-3579. doi:10.1007/s00520-020-05433-w

33. Tang M, Wang S, Zhao B, et al. Traditional Chinese Medicine Prolongs Progression-Free Survival and Enhances Therapeutic Effects in Epidermal Growth Factor Receptor Tyrosine Kinase Inhibitor (EGFR-TKI)Treated Non-Small-Cell Lung Cancer (NSCLC) Patients Harboring EGFR Mutations. Med Sci Monit. 2019;25:8430-8437. doi:10.12659/MSM.917251

34. Xie H, Feng S, Farag MA, Sun P, Shao P. Synergistic cytotoxicity of erianin, a bisbenzyl in the dietetic Chinese herb Dendrobium against breast cancer cells. Food Chem Toxicol. 2021;149:111960. doi:10.1016/j.fct.2020.111960
35. Ma TT, Zhang GL, Dai CF, et al. Scutellaria barbata and Hedyotis diffusa herb pair for breast cancer treatment: potential mechanism based on network pharmacology. $J$ Ethnopharmacol. 2020;259:112929. doi:10.1016/j.jep.2020.112929

36. Li H, Hung A, Yang AWH. Herb-target virtual screening and network pharmacology for prediction of molecular mechanism of Danggui Beimu Kushen Wan for prostate cancer. Sci Rep. 2021;11(1):6656. doi:10.1038/s41598-021-86141-1

37. Gao C, Zhou Y, Jiang Z, et al. Cytotoxic and chemosensitization effects of Scutellarin from traditional Chinese herb Scutellaria altissima L. Human Prostate Cancer Cells Oncol Rep. 2017;38 (3):1491-1499.

38. Li S, Fang Y, Qin H, Fu W, Zhang X. miR-659-3p is involved in the regulation of the chemotherapy response of colorectal cancer via modulating the expression of SPHK1. Am J Cancer Res. 2016;6 (9): 1976

39. Xiong H, Wang J, Guan $\mathrm{H}$, et al. SphK1 confers resistance to apoptosis in gastric cancer cells by downregulating Bim via stimulating Akt/FoxO3a signaling. Oncol Rep. 2014;32(4):1369-1373. doi:10.3892/or.2014.3391

40. Sosa V, Moliné T, Somoza R, Paciucci R, Kondoh H. LLeonart ME. Oxidative Stress Cancer. 2013;12(1):376-390.

41. Seifried HE, McDonald SS, Anderson DE, Greenwald P, Milner JA. The antioxidant conundrum in cancer. Cancer Res. 2003;63 (15):4295-4298.

42. Dahham SS, Tabana YM, Iqbal MA, et al. The anticancer, antioxidant and antimicrobial properties of the sesquiterpene $\beta$-caryophyllene from the essential oil of Aquilaria crassna. Molecules. 2015;20 (7):11808-11829. doi:10.3390/molecules200711808

43. Kong Q, Lillehei K. Antioxidant inhibitors for cancer therapy. Med Hypotheses. 1998;51(5):405-409. doi:10.1016/S0306-9877(98) 90036-6

44. Park K-R, Nam D, Yun H-M, et al. $\beta$-Caryophyllene oxide inhibits growth and induces apoptosis through the suppression of $\mathrm{PI} 3 \mathrm{~K} /$ AKT/mTOR/S6K1 pathways and ROS-mediated MAPKs activation. Cancer Lett. 2011;312(2):178-188. doi:10.1016/j. canlet.2011.08.001

45. Arul S, Rajagopalan H, Ravi J, Dayalan H. Beta-caryophyllene suppresses ovarian cancer proliferation by inducing cell cycle arrest and apoptosis. Anticancer Agents Med Chem. 2020;20 (13):1530-1537. doi:10.2174/1871520620666200227093216
International Journal of General Medicine

\section{Publish your work in this journal}

The International Journal of General Medicine is an international, peer-reviewed open-access journal that focuses on general and internal medicine, pathogenesis, epidemiology, diagnosis, monitoring and treatment protocols. The journal is characterized by the rapid reporting of reviews, original research and clinical studies across all disease areas. The manuscript management system is completely online and includes a very quick and fair peer-review system, which is all easy to use. Visit http://www.dovepress.com/ testimonials.php to read real quotes from published authors. 